\title{
U.S. DEPARTMENT OF ENERGY NEVADA OPERATIONS OFFICE ENVIRONMENTAL MONITORING PROGRAM SUMMARY DATA REPORT SECOND CALENDAR QUARTER 1996
}

February 1997

\author{
RECFIVFO
}

APR 241997

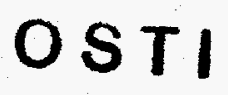

\section{Work Performed Under \\ Contract No. DE-AC08-96NV11718}

Prepared for the:

U.S. Department of Energy

Nevada Operations Office

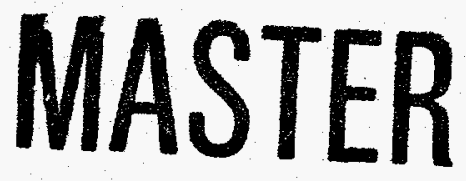

DISTRIBUTION OF THIS DOCUMENT IS UNLIMITED HH

Prepared by:

Bechtel Nevada

Post Office Box 98521

Las Vegas, Nevada 89193-8521 
This report has been reproduced directly from the best available copy.

Available to DOE and DOE contractors from the:

Office of Scientific and Technical Information

P.O. Box 62

Oak Ridge, Tennessee 37831

Prices available from (423) 576-8401

Available to public from the:

National Technical Information Service

U.S. Department of Commerce

5285 Port Royal Rd.

Springfield, VA 22161

Prices available from (703) 487-4650 


\section{ERRATA SHEET}

The following applies to data in the First Calendar Quarter 1996 Report, DOE/NV/11719-046.

In Table 6.0 of the subject report, the ${ }^{239+240} \mathrm{Pu}$ data for the water sample collected from the Area 23 (Mercury) sewage pond was reported as $7.2 \times 10^{-10} \mu \mathrm{Ci} / \mathrm{mL}(0.72 \mathrm{pCi} / \mathrm{L})$. This concentration was greater than the MDC for the analysis, but the value was reported pending reanalysis of another aliquot from the sample. The reanalysis also indicated a detectable amount of plutonium in the sample. Samples from the influent to this pond, before and after this one, have always been below the MDC. Investigation of this anomalous concentration is continuing. 


\section{DISCLAIMER}

This report was prepared as an account of work sponsored by an agency of the United States Government. Neither the United States Government nor any agency thereof, nor any of their employees, make any warranty, express or implied, or assumes any legal liability or responsibility for the accuracy, completeness, or usefulness of any information, apparatus, product, or process disclosed, or represents that its use would not infringe privately owned rights. Reference herein to any specific commercial product, process, or service by trade name, trademark, manufacturer, or otherwise does not necessarily constitute or imply its endorsement, recommendation, or favoring by the United States Government or any agency thereof. The views and opinions of authors expressed herein do not necessarily state or reflect those of the United States Government or any agency thereof. 


\section{DISCLAMIER}

Portions of this document may be illegible in electronic image products. Images are produced from the best available original document. 


\section{U.S. DEPARTMENT OF ENERGY NEVADA OPERATIONS OFFICE ENVIRONMENTAL MONITORING PROGRAM SUMMARY DATA REPORT SECOND CALENDAR QUARTER 1996}

Editors: Stuart C. Black and Yvonne E. Townsend

February 1997

Work Performed Under

Contract No. DE-AC08-96NV11718

Prepared for the:

U.S. Department of Energy

Nevada Operations Office

Prepared by:

Bechtel Nevada

Post Office Box 98521

Las Vegas, Nevada 89193-8521 



\section{ACKNOWLEDGMENTS}

The word processing and desktop publishing support provided by Angela L. McCurdy were crucial to the production of this report. Frank R. Grossman and Bennie S. Hooda compiled and verified radiological onsite data; Orin Haworth provided the non-radiological data; Brian Dozier provided radiological waste management site (RWMS) data; and Cathy Wills provided information on ecological studies. R. R. Kinnison provided the statistical analyses necessary for this report. 



\section{TABLE OF CONTENTS}

Page

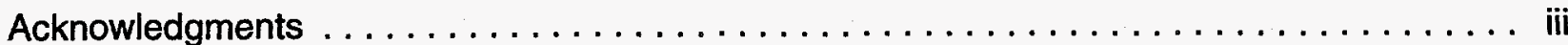

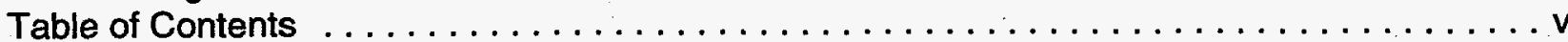

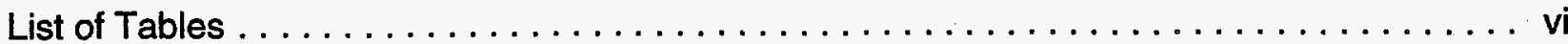

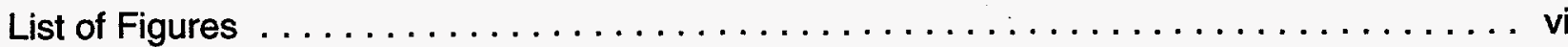

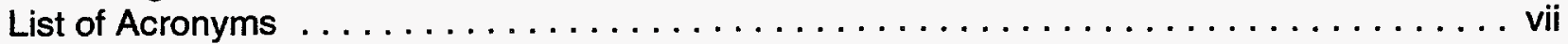

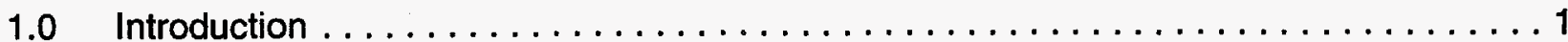

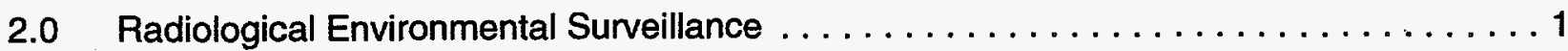

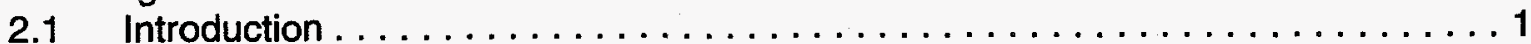

2.2 Radioactivity in Air . . . . . . . . . . . . . . . . . . . . .

2.2.1 Air Particulate/Halogen Sampling Results . . . . . . . . . . . 5

2.2.1.1 Gross Alpha, Gross Beta, and Gamma Spectral Analyses . . . 5

2.2.1.2 Nellis Range Complex Samples . . . . . . . . . . . . 6

2.2.1.3 Plutonium Analyses . . . . . . . . . . . . . . . . 6

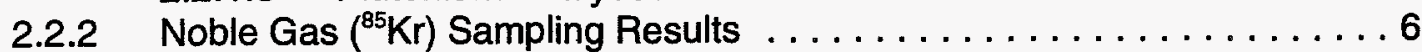

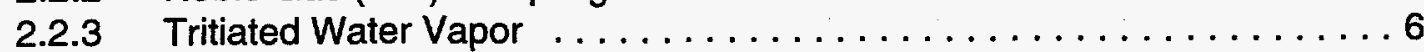

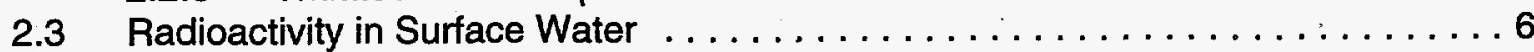

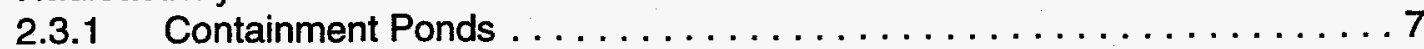

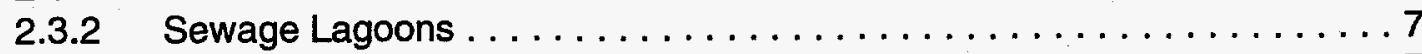

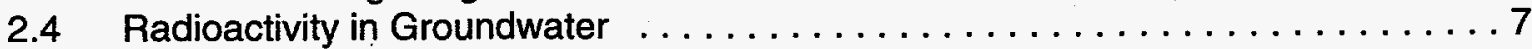

2.4.1 Supply Well Water $\ldots \ldots \ldots \ldots \ldots \ldots \ldots \ldots \ldots \ldots \ldots \ldots \ldots$

2.4.1.1 Gross Beta Results . . . . . . . . . . . . . 8

2.4.1.2 Tritium Results $\ldots \ldots \ldots \ldots \ldots \ldots \ldots \ldots \ldots \ldots$

2.4.1.3 Plutonium Results . . . . . . . . . . . . . . . 8

2.4.1.4 Gross Alpha and Radium Results $\ldots \ldots \ldots \ldots \ldots \ldots$

2.4.1.5 Strontium Results . . ................. 9

2.4.1.6 Gamma Spectroscopy Results $\ldots \ldots \ldots \ldots \ldots \ldots$

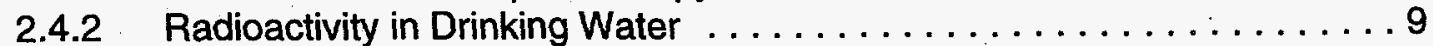

2.4.2.1 Gross Beta Results . . . . . . . . . . . . . . 9

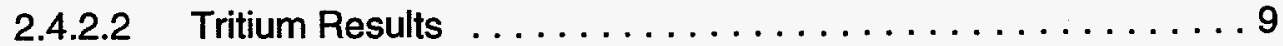

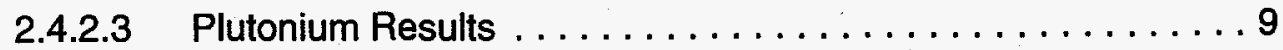

2.4.2.4 Gross Alpha Results . . . . . . . . . . . . . . 10

2.4.2.5 Strontium Results . . . . . . . . . . . . . . 10

2.4.2.6 Gamma Spectroscopy Results . . . . . . . . . . . 10

2.5 External Gamma Exposure Measurement . . . . . . . . . . . . . . . . 10

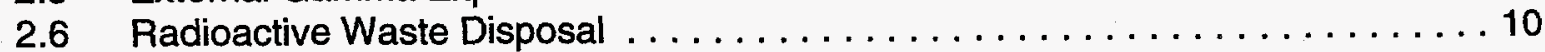

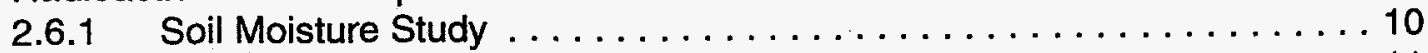

2.6.2 Fauna Study . . . . . . . . . . . . . . . . . . . . 11

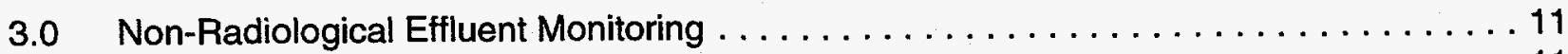

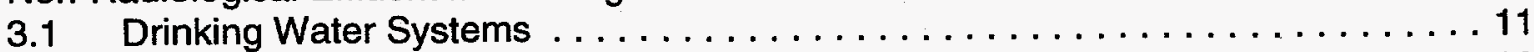

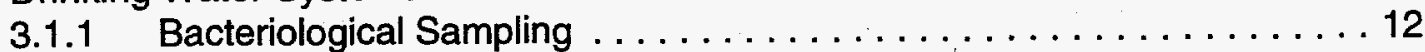

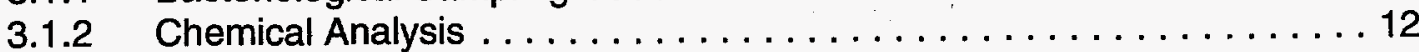

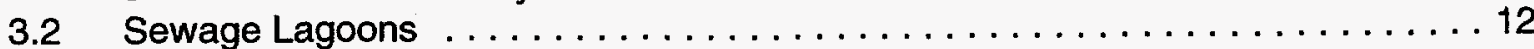




\section{Table of Contents, cont.}

4.0 Non-Hazardous Solid Waste Disposal . . . . . . . . . . . . . . . . . 12

$5.0 \quad$ National Environmental Policy Act . . . . . . . . . . . . . . . . . . . 12

5.1 Environmental Restoration/Remedial Activities $\ldots \ldots \ldots \ldots \ldots \ldots \ldots \ldots \ldots 13$

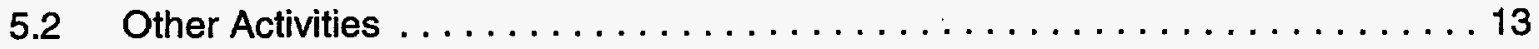

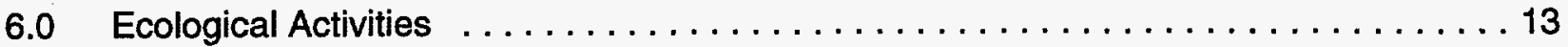

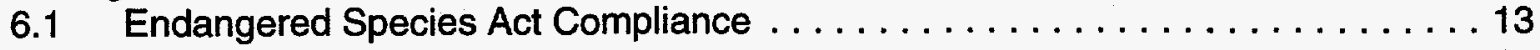

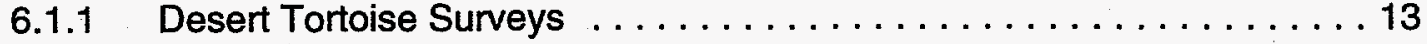

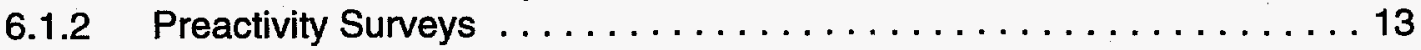

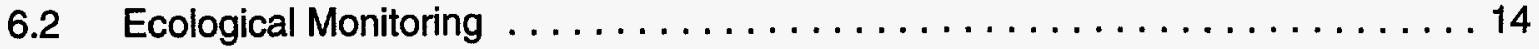

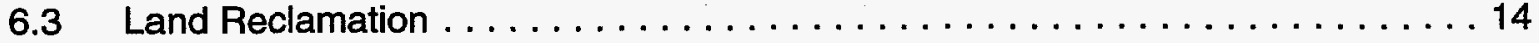

6.3.1 Double Tracks Safety Shot Site . . . . . . . . . . . . . . . . . 14

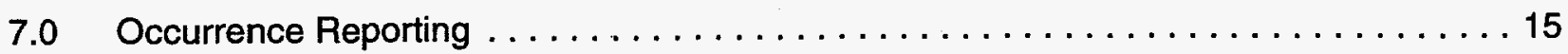

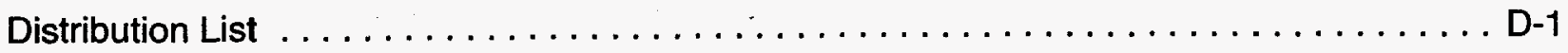




\section{LIST OF TABLES}

Page

Table 1.0 Sample Collection and Analysis Schedule ..................... 17

Table 2.0 Derived Limits for Radionuclides in Air and Water (DOE Order 5400.5) . . . . . . 17

Table 3.0 Summary Data for Gross $\alpha$, Gross $\beta$, and ${ }^{7} \mathrm{Be}$ in $\mathrm{Air}(\mu \mathrm{Ci} / \mathrm{mL})$,

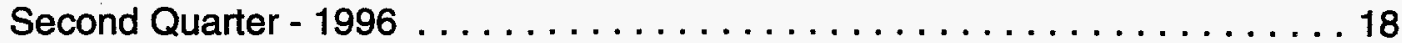

Table 4.0 Offsite Particulate and Onsite ${ }^{85} \mathrm{Kr}$ in Air Summary Data,

Second Quarter - 1996. ............................ 19

Table 5.0 Summary Data for Plutonium in Air Samples, First Quarter - 1996 (a) . . . . . . 19

Table 6.0 Tritium in Atmospheric Moisture Summary Data, Second Quarter - 1996. . . . . . 20

Table 7.0 Summary Data for Well and Surface Water Samples, Second Quarter - 1996 . . . 21

Table 8.0 Faucet Water Sample Summary Results $(\mu \mathrm{Ci} / \mathrm{mL})$, Second Quarter - 1996. . . . . 22

Table 9.0 Background Radiation Measurements with TLDs, First Quarter - 1996 ${ }^{\text {(a) }} \ldots \ldots .22$

Table 10.0 Tritium in Soil Moisture, RWMS-5 $-\mathrm{nCi} / \mathrm{m}^{3} \ldots \ldots \ldots \ldots \ldots \ldots \ldots \ldots \ldots \ldots \ldots \ldots \ldots \ldots$

Table 11.0 Pond Water Depths in Infiltration Basins, Second Quarter - $1996 \ldots \ldots \ldots \ldots \ldots 23$

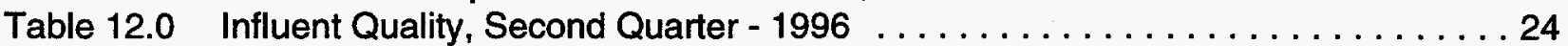

Table 13.0 Organic Loading Rates, Second Quarter - $1996 \ldots \ldots \ldots \ldots \ldots \ldots \ldots \ldots 24$

Table 14.0 Influent Toxics for Facilities that Receive Industrial Wastewater,

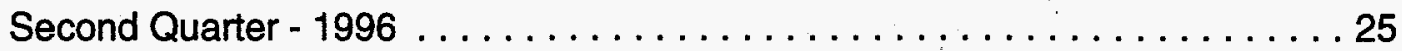

Table 15.0 Quantity of Waste Disposed of in Landfills, Second Quarter - 1996 . . . . . . . . 25

Table 16.0 NEPA Documentation Open, Second Quarter - $1996 \ldots \ldots \ldots \ldots \ldots \ldots 26$

Table 17.0 Environmental Occurrences at NTS Facilities, Second Quarter - $1996 \ldots \ldots 27$

\section{LIST OF FIGURES}

Page

Figure 1.0 Location of NTS Air Sampling Stations, $1996 \ldots \ldots \ldots \ldots \ldots \ldots \ldots \ldots$

Figure 2.0 Location of NTS Water Sampling Stations, $1996 \ldots \ldots \ldots \ldots \ldots \ldots \ldots$

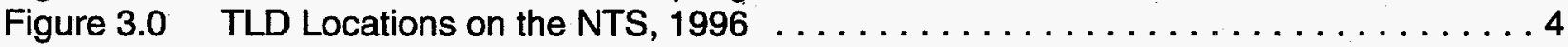

Figure 4.0 Tritium in Soil Moisture at RWMS-5 (MON-57 $=$ month 57$) \ldots \ldots \ldots \ldots \ldots$ 


\section{LIST OF ACRONYMS}

$\begin{array}{ll}\text { CX } & \text { Categorical Exclusion } \\ \text { DAF } & \text { Device Assembly Facility } \\ \text { DCG } & \text { Derived Concentration Guides } \\ \text { DOE } & \text { U.S. Department of Energy } \\ \text { DOE/NV } & \text { DOE Nevada Operations Office } \\ \text { EA } & \text { Environmental Assessment } \\ \text { EDE } & \text { Effective Dose Equivalent } \\ \text { EIS } & \text { Environmental Impact Statement } \\ \text { EPA } & \text { U.S. Environmental Protection Agency } \\ \text { HAZMAT } & \text { Hazardous Materials } \\ \text { HTO } & \text { tritiated water } \\ \text { LANL } & \text { Los Alamos National Laboratory } \\ \text { LGFSTF } & \text { Liquefied Gaseous Fuels Spill Test Facility } \\ \text { LLNL } & \text { Lawrence Livermore National Laboratory } \\ \text { LLW } & \text { Low-Level Waste } \\ \text { MDC } & \text { Minimum Detectable Concentration } \\ \text { NEPA } & \text { National Environmental Policy Act } \\ \text { NTS } & \text { Nevada Test Site } \\ \text { RWMS-3 } & \text { Radioactive Waste Management Site, Area 3 } \\ \text { RWMS-5 } & \text { Radioactive Waste Management Site, Area 5 } \\ \text { SDWA } & \text { Safe Drinking Water Act } \\ \text { TLD } & \text { thermoluminescent dosimeter } \\ \text { TTR } & \text { Tonopah Test Range } \\ \text { USFWS } & \text { U.S. Fish and Wildlife Service }\end{array}$




\subsection{INTRODUCTION}

The Nevada Test Site (NTS), located in southern Nevada, has been the primary location for testing of nuclear explosives in the continental U.S. Testing began in 1951 and continued until the moratorium in 1992. Historically, nuclear testing has included: atmospheric testing in the 1950 s and early 1960s; underground testing in drilled, vertical holes and horizontal tunnels; earth-cratering experiments; and open-air nuclear reactor and engine testing. No nuclear explosives tests have been conducted in 1996. Non-nuclear testing includes controlled spills of hazardous material and tests of an incinerator device at the Liquefied Gaseous Fuels Spill Test Facility (LGFSTF) (now called the Hazardous Materials [HAZMAT] Spill Center). Low-level radioactive and mixed waste disposal and storage facilities for defense waste are also operated on the NTS. At the Explosive Ordnance Disposal, explosive materials are destroyed, generally by detonation, with the amounts destroyed being limited to maintain downwind air concentrations within state limits.

Waste storage and disposal facilities for defense radioactive and mixed waste are located in Areas 3 and 5. At the Area 5 Radioactive Waste Management Site (RWMS-5), low-level wastes (LLW) from U.S. Department of Energy (DOE) affiliated onsite and offsite generators are disposed of using standard shallow land disposal techniques. Transuranic wastes are retrievably stored at the RWMS-5 in containers on a surface pad, pending shipment to the Waste Isolation Pilot Plant facility in New Mexico. Nonradioactive hazardous wastes are accumulated at a special site before shipment to a licensed offsite disposal facility. Nonstandard packages of LLW are buried in subsidence craters in the Area 3 RWMS (RWMS-3).

This report describes these activities on and around the NTS and includes a listing of the results obtained from environmental surveillance activities during the second calendar quarter of 1996.

\subsection{RADIOLOGICAL ENVIRONMENTAL SURVEILLANCE}

\subsection{INTRODUCTION}

The continuing moratorium on the testing of nuclear explosive devices, the possibility of alternate uses for the NTS, and a reduced budget have led to significant changes in the extent of environmental radiological surveillance activities on and around the NTS. Not only have the number of monitored locations been reduced, but also the frequency and types of analyses have been changed. The present onsite radiological surveillance program is outlined in Table 1.0 .

During the second calendar quarter of 1996, air samples were collected and analyzed from 45 air particulate/halogen sampling stations, 3 noble gas sampling stations, and 15 tritiated water (HTO) vapor sampling stations. Surface water samples were collected and analyzed from 1 tunnel water containment pond, and 9 sewage lagoons. Groundwater samples were obtained from 10 potable and 2 non-potable supply wells and from 7 drinking water end points, called faucet samples. Ambient radiation levels were measured by use of thermoluminescent dosimeters (TLDs) placed at 168 locations on the NTS. The sampling station locations are shown in Figures 1.0, 2.0, and 3.0. These activities were conducted in accordance with the schedule set forth in Table 1.0 . 


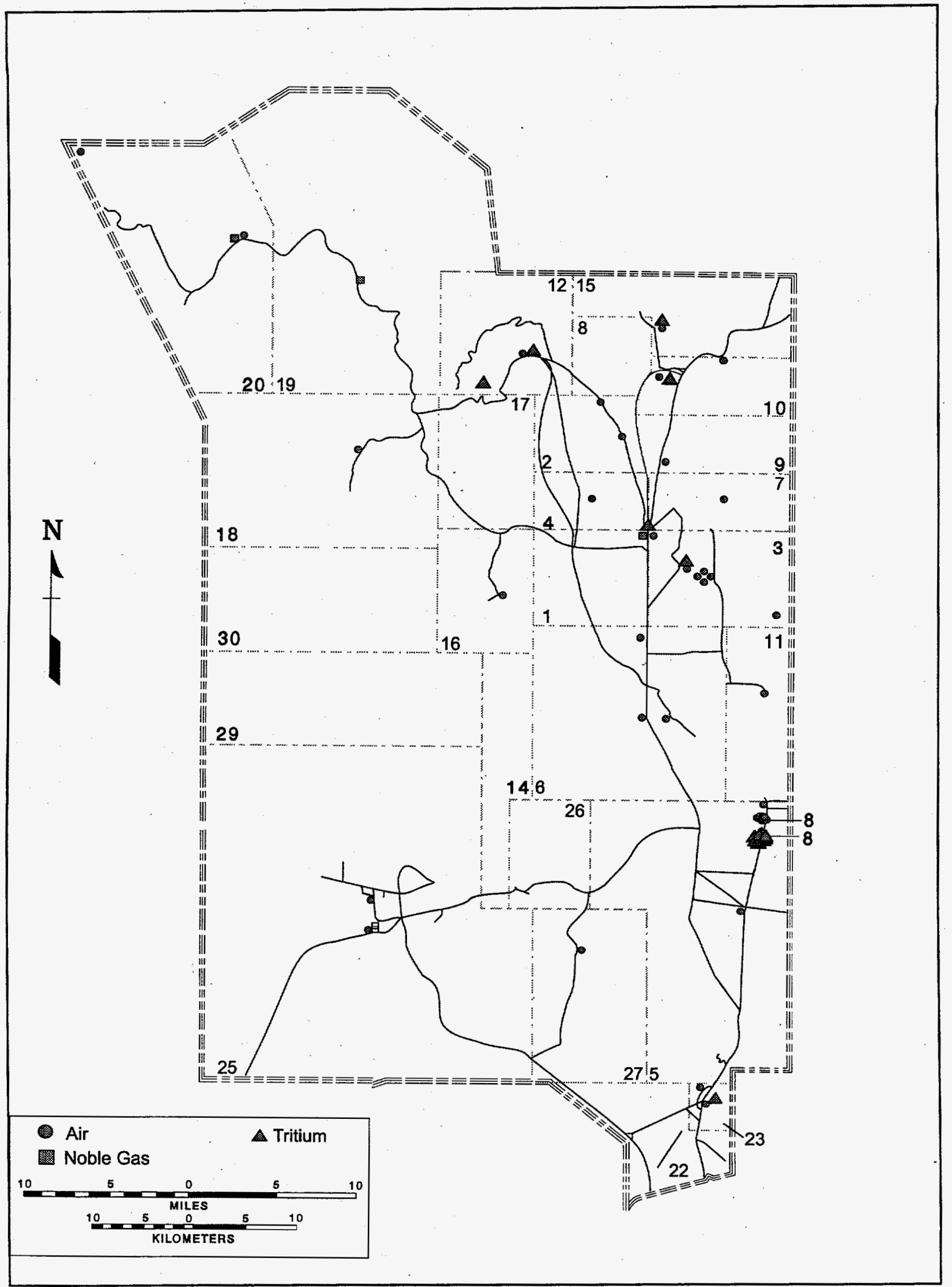

Figure 1.0 Location of NTS Air Sampling Stations, 1996 


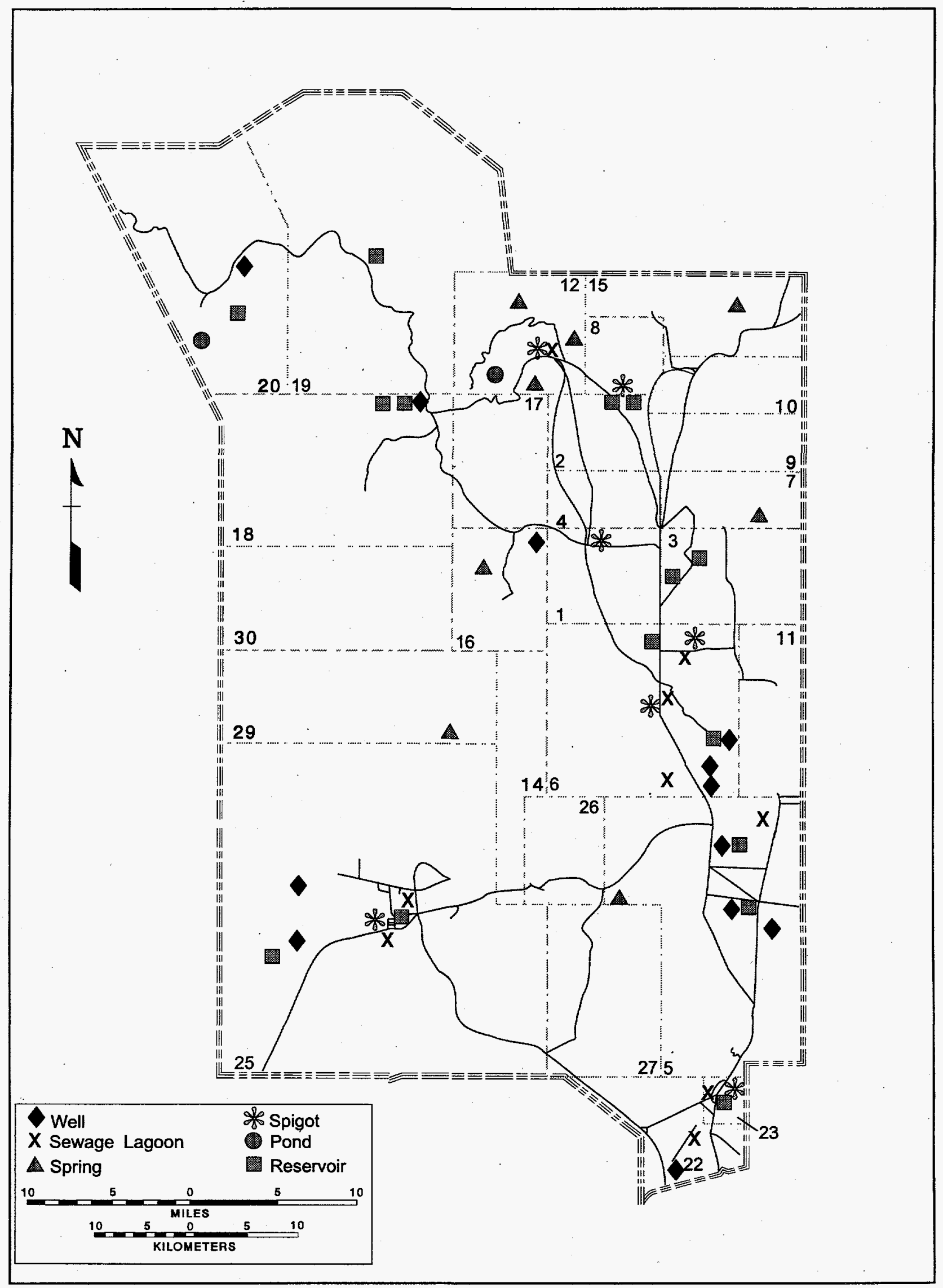

Figure 2.0 Location of NTS Water Sampling Stations, 1996 


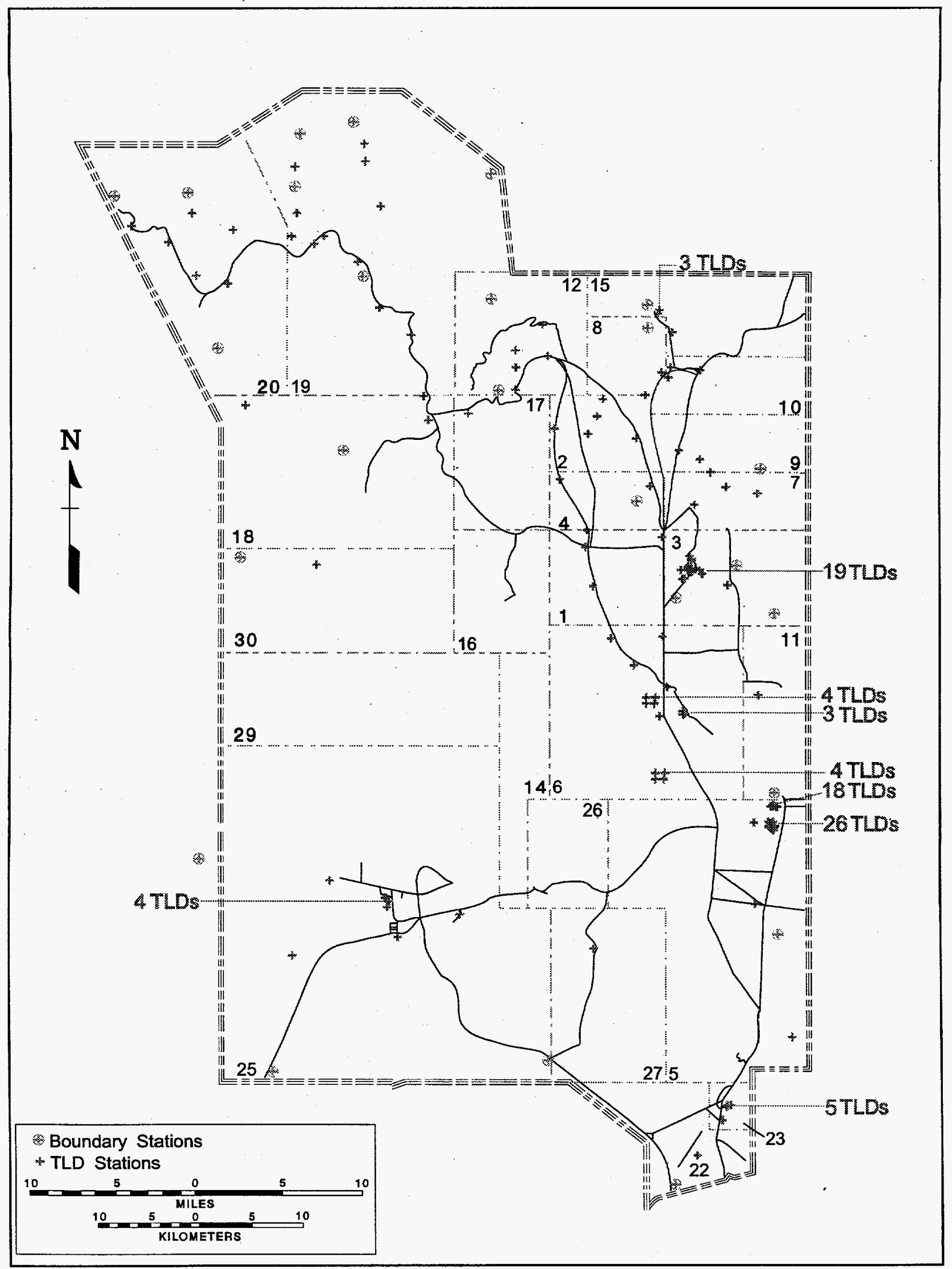

Figure 3.0 TLD Locations on the NTS, 1996 


\subsection{RADIOACTIVITY IN AIR}

The 45 air particulate/halogen sampling stations were operated continuously. Samples were collected weekly on glass fiber filters (for particulates) and charcoal cartridges (for halogens). The filters were counted for gamma and gross beta activity, composited either monthly or quarterly, and then analyzed for ${ }^{238} \mathrm{Pu}$ and ${ }^{239+240} \mathrm{Pu}$. Unless indicated by radioactivity detected on the glass fiber filters, the charcoal cartridges were not analyzed.

Samples for the noble gas ${ }^{85} \mathrm{Kr}$ were collected weekly at three fixed locations by pumping air into pressure bottles. A cryogenic distillation process separated the krypton gas from the air sample. The krypton was then dissolved in a scintillation cocktail and measured by use of liquid-scintillation counting.

Tritiated water vapor was continuously collected on silica gel at 15 locations. The silica gel was exchanged every two weeks and the collected sample then heated to extract the water which was analyzed for ${ }^{3} \mathrm{H}$ by use of liquid-scintillation counting.

Measured quantities of radioactivity were compared to the Derived Concentration Guides (DCGs) found in DOE Order 5400.5. DCGs are used to compare the radiation exposure of the general public to regulatory limits. The values used are listed in Table 2.0. In making these comparisons, the following assumptions were made:

- The chemical species of the radionuclides were unknown so the most restrictive DCG values were used. These DCG values were also adjusted in order to demonstrate compliance with requirements of 40 CFR 61, National Emission Standards for Hazardous Air Pollutants, and 40 CFR 141, Safe Drinking Water Act.

- For air sampling results, all of the gross beta activity detected was assumed to be ${ }^{90} \mathrm{Sr}$.

\subsubsection{AIR PARTICULATE/HALOGEN SAMPLING RESULTS}

Some of the locations that were necessary for an effective monitoring design were in sites where commercial electric power was unavailable so solar-powered stations were used. These have been installed at Well ER-3-1, Bunker T-4, SEDAN Crater, Well UE-18t, and the SCHOONER site and also at offsite locations in the Nellis Range Complex, namely, the Area 13 site, the DOUBLE TRACKS site, and the CLEAN SLATES site.

\subsubsection{GROSS ALPHA, GROSS BETA, AND GAMMA SPECTRAL ANALYSES}

Many of the particulate samples were analyzed for gross alpha radioactivity. This has not been done for several years but may be useful as an early indicator since this analysis can be completed in a week or two versus a month or two for plutonium analysis. The network mean was $2.6 \times 10^{-15} \mu \mathrm{Ci} / \mathrm{mL}$ ( $\left.96 \mu \mathrm{Bq} / \mathrm{L}\right)$. Air particulate samples were held for 5 to 7 days prior to gross beta counting and gamma spectral analysis to allow for the decay of radon progeny. Summary data for gross beta results are shown in Table 3.0. Results exceeded their applicable minimum detectable concentration (MDC). Mean station concentrations ranged from 1.27 to $3.24 \times 10^{-14} \mu \mathrm{Ci} / \mathrm{mL}\left(0.47\right.$ to $\left.1.2 \mathrm{mBq} / \mathrm{m}^{3}\right)$. The network mean gross beta concentration was $1.71 \times 10^{-14} \mu \mathrm{Ci} / \mathrm{mL}\left(0.63 \mathrm{mBq} / \mathrm{m}^{3}\right)$. This concentration is 1.9 percent of the $\mathrm{DCG}$ for ${ }^{90} \mathrm{Sr}$ in DOE Order 5400.5 adjusted to an annual Effective Dose Equivalent (EDE) of $10 \mathrm{mrem}(0.1$ $\mathrm{mSv}$ ) in accordance with the requirements of 40 CFR 61 . The network mean is slightly lower than the values observed during the past 7 years $(1989-1995)$. 
Glass fiber filters used to collect particulates were analyzed by gamma spectroscopy. Charcoal cartridges, collected concurrently with the filters, were only analyzed if the result of fiber filter analysis indicated the potential for halogens. No such results were observed for the second quarter of 1996. Radionuclides detected were naturally occurring in the environment $\left({ }^{40} \mathrm{~K},{ }^{7} \mathrm{Be}\right.$, and members of the uranium and thorium series), except for near MDC concentrations of ${ }^{137} \mathrm{Cs}$ detected in one sample each in Areas 9 and 27. The ${ }^{7}$ Be results are also shown in Table 3.0 and are similar to the results for 1993, 1994, and 1995.

\subsubsection{NELLIS RANGE COMPLEX SAMPLES}

The samples collected from the Area 13, the DOUBLE TRACKS, and the CLEAN SLATE sites were analyzed for gross beta and gamma activity (see Table 4.0). The gross beta average of $1.55 \times 10^{-14} \mu \mathrm{Ci} / \mathrm{mL}\left(0.57 \mathrm{mBq} / \mathrm{m}^{3}\right)$ is similar to the onsite average data as is the ${ }^{7} \mathrm{Be}$ result of $2.97 \times 10^{-13} \mu \mathrm{Ci} / \mathrm{mL}\left(11 \mathrm{mBq} / \mathrm{m}^{3}\right)$ from gamma analysis of the filters.

\subsubsection{PLUTONIUM ANALYSES}

Filters from each particulate sampling station, located on the boundary of the RWMS-5 (eight stations) and RWMS-3 (four stations) were composited monthly and analyzed for ${ }^{238} \mathrm{Pu}$ and ${ }^{239+240} \mathrm{Pu}$. Filters from all other particulate sampling stations were composited quarterly and analyzed for plutonium isotopes.

These analyses have not been completed for all stations for the second quarter of 1996 and the results validated. However, air monitoring results for ${ }^{238} \mathrm{Pu}$ and ${ }^{239+240} \mathrm{Pu}$ for the first quarter are now available. The results are summarized in Table 5.0 and are consistent with previous data.

\subsubsection{NOBLE GAS $\left({ }^{85} \mathrm{Kr}\right)$ SAMPLING RESULTS}

Noble gas analyses for the second quarter of 1996 have been completed and the results validated. The network average for the three stations sampled this quarter is $41 \mathrm{pCi} / \mathrm{m}^{3}$ $\left(1.5 \mathrm{~Bq} / \mathrm{m}^{3}\right)$ of ${ }^{85} \mathrm{Kr}$, which is higher than the annual average for the past several years of about $26 \mathrm{pCi} / \mathrm{m}^{3}$. Xenon-133 analyses have been discontinued because of the moratorium on nuclear tests. Table 4.0 contains the available results.

\subsubsection{TRITIATED WATER VAPOR}

Summary data for HTO vapor sampling are shown in Table 6.0. Mean station concentrations ranged from 0.42 to $10 \times 10^{-12} \mu \mathrm{Ci} / \mathrm{mL}\left(16\right.$ to $\left.370 \mathrm{mBq} / \mathrm{m}^{3}\right)$. The network mean concentration was $3.0 \times 10^{-12} \mu \mathrm{Ci} / \mathrm{mL}\left(110 \mathrm{mBq} / \mathrm{m}^{3}\right)$. This network mean is similar to other quarterly means. The highest mean value was measured at the $E$ Tunnel Pond station but was only 0.1 percent of the DCG for tritium adjusted for an annual EDE of $10 \mathrm{mrem}$.

\subsection{RADIOACTIVITY IN SURFACE WATER}

Annual samples are taken at all open reservoirs and natural springs. Quarterly samples are taken at any active containment ponds. Samples are analyzed for gross beta activity and for tritium, ${ }^{238} \mathrm{Pu},{ }^{239+240} \mathrm{Pu},{ }^{90} \mathrm{Sr}$, and gamma-emitting radionuclides. 
Samples were not collected at any of the reservoirs or springs during this quarter. Sampling was limited to Area $12 \mathrm{E}$ Tunnel effluent and E Tunnel pond No. 1. Samples were collected from 7 sewage lagoons as indicated in Table 7.0.

\subsubsection{CONTAINMENT PONDS}

At the Area 12 E Tunnel complex, grab samples were taken from containment pond No. 1 and at the effluent discharge point. The results of analyses for these two samples are given in Table 7.0. These results for $E$ Tunnel samples are slightly less than the results observed in the third quarter of 1995.

\subsubsection{SEWAGE LAGOONS}

Each of the lagoons is part of a closed system used for evaporative treatment of sanitary waste. The lagoons are located in Areas 5, 6, 11, 12, 22, 23, and 25. Quarterly samples were taken and analyzed for gross beta activity and for tritium, ${ }^{238} \mathrm{Pu},{ }^{239+240} \mathrm{Pu}$, and gamma-emitting radionuclides. Summary data for sewage lagoons are shown in Table 7.0.

The gross beta concentrations in the lagoons ranged from 12 to $45 \times 10^{-9} \mu \mathrm{Ci} / \mathrm{mL}$ $(0.44$ to $1.7 \mathrm{~Bq} / \mathrm{L})$ with a network mean of $30 \times 10^{-9} \mu \mathrm{Ci} / \mathrm{mL}(1.1 \mathrm{~Bq} / \mathrm{L})$. Results were above their detection limits. The maximum station mean was at Area 6 Device Assembly Facility (DAF) Pond. These results are consistent with previous data.

The tritium concentrations in the lagoon samples ranged from 22 to $340 \times 10^{-9} \mu \mathrm{Ci} / \mathrm{mL}$ $(0.8$ to $13 \mathrm{~Bq} / \mathrm{L})$. Results were less than their individual detection limits.

Station ${ }^{238} \mathrm{Pu}$ and ${ }^{239+240} \mathrm{Pu}$ maximum concentrations were $0.0002 \times 10^{-9} \mu \mathrm{Ci} / \mathrm{mL}(7.4 \mu \mathrm{Bq} / \mathrm{L})$ for both isotopes. The network means for ${ }^{238} \mathrm{Pu}$ and ${ }^{239+240} \mathrm{Pu}$ were both $-0.005 \times 10^{-9} \mu \mathrm{Ci} / \mathrm{mL}$ $(-18 \mathrm{mBq} / \mathrm{L}) .{ }^{238} \mathrm{Pu}$ and ${ }^{239+240} \mathrm{Pu}$ values were less than their applicable detection limits.

Analyses are performed annually for ${ }^{90} \mathrm{Sr}$ in sewage lagoons but were not done this quarter.

Water samples were analyzed by gamma spectroscopy. Rradionuclides detected were naturally occurring in the environment $\left({ }^{40} \mathrm{~K},{ }^{7} \mathrm{Be}\right.$, and members of the uranium and thorium series). No nuclear event related radioactivity was detected by the gamma spectroscopy analyses.

The results for sewage lagoons discussed above are comparable with past results, and the network means are within the ranges measured during the past 7 years.

\subsection{RADIOACTIVITY IN GROUNDWATER}

The NTS groundwater system is partially monitored by 12 water supply wells, 10 of which supply potable water to onsite distribution systems that are sampled monthly. Two supply wells, Area 5 Well UE-5c and Area 20 Well U-20 supply water for industrial purposes. Another set of wells, sampled less frequently by the Environmental Protection Agency (EPA) Radiation Sciences Laboratory supplies additional information on groundwater. 


\subsubsection{SUPPLY WELL WATER}

The potable wells are sampled quarterly and analyzed for gross alpha/beta activity, tritium (using enrichment procedure), ${ }^{238} \mathrm{Pu},{ }^{239+240} \mathrm{Pu},{ }^{90} \mathrm{Sr},{ }^{226 \& 228} \mathrm{Ra}$, and gamma-emitting radionuclides. The pump for Area 6 Well $\mathrm{C}$ was broken last year and this potable supply well has not been sampled since then. The non-potable wells are also sampled quarterly and receive the same analyses, except for tritium (standard liquid-scintillation analysis) and 226 \& ${ }^{228} \mathrm{Ra}$ (none). Summary data for these supply wells are given in Table 7.0. Results greater than their detection limits for potable wells are compared to the DCGs in DOE 5400.5, as adjusted to meet federal Safe Drinking Water Act (SDWA) regulations or SDWA screening levels.

\subsubsection{GROSS BETA RESULTS}

The station values for gross beta for potable supply wells ranged from 1.2 to $9.2 \times 10^{-9} \mu \mathrm{Ci} / \mathrm{mL}$ ( 0.04 to $0.34 \mathrm{~Bq} / \mathrm{L})$ with a network mean of $7.2 \times 10^{-9} \mu \mathrm{Ci} / \mathrm{mL}(0.27 \mathrm{~Bq} / \mathrm{L})$. The station value for gross beta for the non-potable supply well was $7.3 \times 10^{-9} \mu \mathrm{Ci} / \mathrm{mL}(0.23 \mathrm{~Bq} / \mathrm{L})$. Results were above their detection limits. The maximum potable station value was at Area $5 \mathrm{Well} 5 \mathrm{C}$ and was 31 percent of the SDWA compliance limit for ${ }^{40} \mathrm{~K}$.

\subsubsection{TRITIUM RESULTS}

The station values for tritium for potable supply wells ranged from -0.77 to $4.8 \times 10^{-9} \mu \mathrm{Ci} / \mathrm{mL}$ $(-0.028$ to $0.18 \mathrm{~Bq} / \mathrm{L})$ with a network mean of $1.7 \times 10^{-9} \mu \mathrm{Ci} / \mathrm{mL}(0.06 \mathrm{~Bq} / \mathrm{L})$. The station value for tritium for the non-potable supply well was $0.4 \times 10^{-9} \mu \mathrm{Ci} / \mathrm{mL}(0.015 \mathrm{~Bq} / \mathrm{L})$. Results were less than their detection limits. The maximum tritium value was at Well HTH 8 and was 0.02 percent of the SDWA compliance limit.

\subsubsection{PLUTONIUM RESULTS}

The network mean value for ${ }^{238} \mathrm{Pu}$ for potable supply wells was $0.005 \times 10^{-9} \mu \mathrm{Ci} / \mathrm{mL}(0.2 \mathrm{mBq} / \mathrm{L})$. The network mean value for ${ }^{239+240} \mathrm{Pu}$ for potable supply wells was $0.006 \times 10^{-9} \mu \mathrm{Ci} / \mathrm{mL}$ $(0.22 \mathrm{mBq} / \mathrm{L})$. The station values for ${ }^{238} \mathrm{Pu}$ and ${ }^{239+240} \mathrm{Pu}$ for the non-potable supply well were 0.0082 and $0.0085 \times 10^{-9} \mu \mathrm{Ci} / \mathrm{mL}(0.31$ and $0.33 \mathrm{mBq} / \mathrm{L})$, respectively. Both values were below the mean sample detection limits.

\subsubsection{GROSS ALPHA AND RADIUM RESULTS}

The station values for gross alpha for potable supply wells ranged from 0.92 to $9.6 \times 10^{-9}$ $\mu \mathrm{Ci} / \mathrm{mL}$ (34 to $360 \mathrm{mBq} / \mathrm{L}$ ) with a network mean of $7.3 \times 10^{-9} \mu \mathrm{Ci} / \mathrm{mL}(270 \mathrm{mBq} / \mathrm{L})$. The gross alpha value for the non-potable supply well was $9.2 \times 10^{-9} \mu \mathrm{Ci} / \mathrm{mL}(0.34 \mathrm{~Bq} / \mathrm{L})$. Results were above their detection limits. Several potable supply well results exceeded the SDWA screening level of $5 \mathrm{pCi} / \mathrm{L}$ for gross alpha.

The potable water well station values for ${ }^{226} \mathrm{Ra}$ ranged up to $2.9 \times 10^{-9} \mu \mathrm{Ci} / \mathrm{mL}(0.11 \mathrm{~Bq} / \mathrm{L})$ with a network mean of $1.1 \times 10^{-9} \mu \mathrm{Ci} / \mathrm{mL}(41 \mathrm{mBq} / \mathrm{L})$. The potable station means for ${ }^{228} \mathrm{Ra}$ were less than the MDC with a network mean of $0.43 \times 10^{-9} \mu \mathrm{Ci} / \mathrm{mL}(16 \mathrm{mBq} / \mathrm{L})$. Most of the ${ }^{226} \mathrm{Ra}$ results were also less than their detection limits. The highest result was at Well C-1 and was 58 percent of the applicable adjusted DCG. 


\subsection{1:5 STRONTIUM RESULTS}

The maximum station value for potable supply wells for ${ }^{90} \mathrm{Sr}$ was $0.16 \times 10^{-9} \mu \mathrm{Ci} / \mathrm{mL}(5.9 \mathrm{mBq} / \mathrm{L})$ with a network mean of $0.06 \times 10^{-9} \mu \mathrm{Ci} / \mathrm{mL}(2.2 \mathrm{mBq} / \mathrm{L})$. The value for the non-potable supply well was $0.059 \times 10^{-9} \mu \mathrm{Ci} / \mathrm{mL}(2.2 \mathrm{mBq} / \mathrm{L})$. Station values were below their detection limits.

\subsubsection{GAMMA SPECTROSCOPY RESULTS}

Water samples were analyzed by gamma spectroscopy, but the only radionuclides detected were naturally occurring in the environment $\left({ }^{40} \mathrm{~K},{ }^{7} \mathrm{Be}\right.$, and members of the uranium and thorium series). No nuclear event-related radioactivity was detected by the gamma spectroscopy analyses.

The results for supply wells discussed above are generally comparable with past results. Network means were within the range of means measured during the past six years, except for the ${ }^{90} \mathrm{Sr}$ concentrations which are slightly lower than has been observed previously.

\subsubsection{RADIOACTIVITY IN DRINKING WATER}

As a check on any effect the water distribution system might have on water quality, samples were collected from water faucets at seven locations. These are at the end-points of the NTS drinking water supply systems.

Samples are collected from these faucets quarterly and analyzed for gross alpha and gross beta activity, tritium, ${ }^{238} \mathrm{Pu},{ }^{239+240} \mathrm{Pu}$, and gamma-emitting radionuclides. Summary data for the samples are given in Table 8.0. Results greater than the sample detection limits are compared to the DCGs in DOE 5400.5 as adjusted to meet federal SDWA regulations, or SDWA compliance or screening levels.

\subsubsection{GROSS BETA RESULTS}

The station values for gross beta ranged from 3.9 to $10.2 \times 10^{-9} \mu \mathrm{Ci} / \mathrm{mL}(0.1$ to $0.38 \mathrm{~Bq} / \mathrm{L})$ with a network mean of $6.5 \times 10^{-9} \mu \mathrm{Ci} / \mathrm{mL}(0.24 \mathrm{~Bq} / \mathrm{L})$. All of these values were above their detection limits. The maximum station value was at Mercury (Cafeteria) and was 20 percent of the SDWA compliance limit.

\subsubsection{TRITIUM RESULTS}

The station values for tritium ranged from -140 to $340 \times 10^{-9} \mu \mathrm{Ci} / \mathrm{mL}(-5.2$ to $13 \mathrm{~Bq} / \mathrm{L})$ with a network mean of $77 \times 10^{-9} \mu \mathrm{Ci} / \mathrm{mL}(2.8 \mathrm{~Bq} / \mathrm{L})$. Values were less than the sample detection limits.

\subsubsection{PLUTONIUM RESULTS}

The station values for both ${ }^{238} \mathrm{Pu}$ and ${ }^{239+240} \mathrm{Pu}$ ranged up to $-0.002 \times 10^{-9} \mu \mathrm{Ci} / \mathrm{mL}(-0.11 \mathrm{mBq} / \mathrm{L})$ with a network mean of $-0.006 \times 10^{-9} \mu \mathrm{Ci} / \mathrm{mL}(-0.22 \mathrm{mBq} / \mathrm{L})$. Station values for both ${ }^{238} \mathrm{Pu}$ and ${ }^{239+240} \mathrm{Pu}$ were below their detection limits. 


\subsubsection{GROSS ALPHA RESULTS}

The station values for gross alpha ranged from 0.9 to $9.8 \times 10^{-9} \mu \mathrm{Ci} / \mathrm{mL}(0.033$ to $0.36 \mathrm{~Bq} / \mathrm{L})$ with a network mean of $4.6 \times 10^{-9} \mu \mathrm{Ci} / \mathrm{mL}(0.17 \mathrm{~Bq} / \mathrm{L})$. Results were above their detection limits, except for the Building 12-23 sample. Four results exceeded the SDWA screening level for gross alpha.

\subsubsection{STRONTIUM RESULTS}

Analyses are performed annually for ${ }^{90} \mathrm{Sr}$ in faucet samples but were not done this quarter.

\subsubsection{GAMMA SPECTROSCOPY RESULTS}

Water samples were analyzed by gamma spectroscopy. The only radionuclides detected were naturally occurring in the environment $\left({ }^{40} \mathrm{~K},{ }^{7} \mathrm{Be}\right.$, and members of the uranium and thorium series). No nuclear event-related radioactivity was detected by the gamma spectroscopy analyses.

The results for the faucet samples discussed above are generally comparable with past results. All network means are within the range of means measured during the past few years.

\subsection{EXTERNAL GAMMA EXPOSURE MEASUREMENT}

External gamma exposure on the NTS is measured by use of TLDs. There are 168 TLDs placed at locations on the NTS to measure background radiation, radiation from contaminated areas, and radiation from various facilities. The background measurements are made at 26 locations, 9 control sites on the NTS, and 17 that are near the site boundary. The results of the background measurements are shown in Table 9.0; they are consistent with previous measurements.

\subsection{RADIOACTIVE WASTE DISPOSAL}

During the first calendar quarter of 1996, LLW amounting to 2.45 curies (614 packages weighing 232.5 metric tons, occupying $372 \mathrm{~m}^{3}$ ) was accepted at the RWMS-3 and RWMS-5 facilities for disposal. A larger amount was accepted for disposal at the two facilities during the second quarter, namely, $3172 \mathrm{Ci}$ in 1890 metric tons of waste occupying $3550 \mathrm{~m}^{3}$, shipped in 984 packages.

No mixed waste was accepted for disposal at the RWMS-5 permitted site.

\subsubsection{SOIL MOISTURE STUDY}

In one of the greater confinement disposal holes at RWMS-5, samples of soil gas were taken at various depths and the tritium (as HTO) concentration measured. The results are shown in Table 10.0 and displayed graphically in Figure 4.0. Apparently the HTO released from LLW packages, although continued for almost 5 years, is confined to a layer of soil extending from 70 to $110 \mathrm{ft}$ below ground surface. 


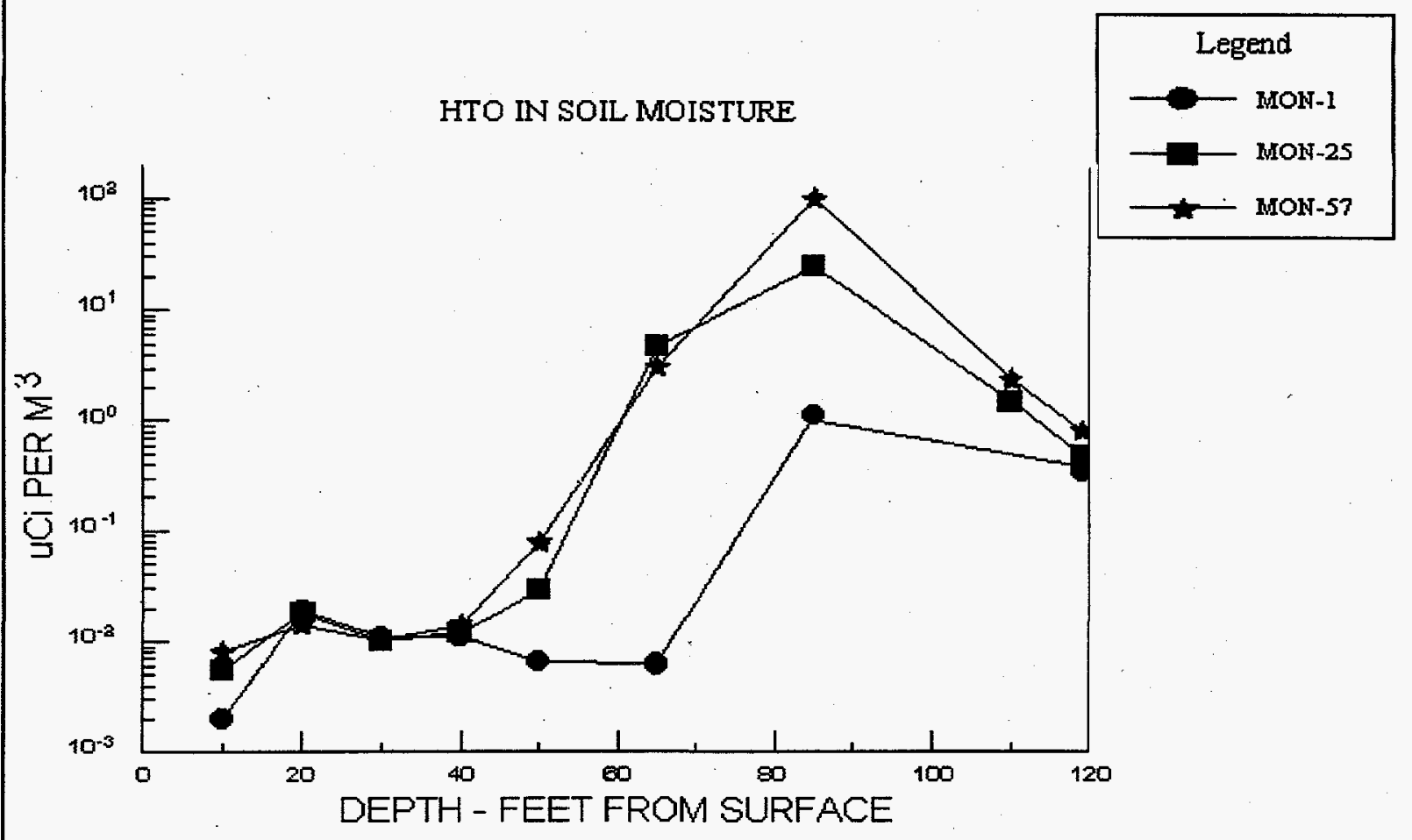

Figure 4.0 Tritium in Soil Moisture at RWMS-5 (MON-57 = month 57)

\subsubsection{FAUNA STUDY}

In October 1994, 18 kangaroo rats and 3 antelope ground squirrels were trapped near RWMS-5 and blood samples taken. The samples were analyzed for HTO and for gamma emitters. The average $\mathrm{HTO}$ concentration in 17 rats was $3.8 \mathrm{nCi} / \mathrm{mL}$ and in 3 squirrels $0.88 \mathrm{nCi} / \mathrm{mL}$. The kangaroo rat with the maximum blood concentration of tritium would have received a dose equivalent of 1.3 rem per year.

\subsection{NON-RADIOLOGICAL EFFLUENT MONITORING}

\subsection{DRINKING WATER SYSTEMS}

Water sampling was conducted for analysis of bacteria in the water as required by the federal SDWA and state of Nevada regulations. Samples were taken at various locations throughout all drinking water distribution systems on the NTS. Common sampling points were restroom and cafeteria sinks. Samples were also collected this quarter for inorganic and organic analyses. Analyses were performed in accordance with Nevada Administrative Code 445 and 40 CFR Part 141. 


\subsubsection{BACTERIOLOGICAL SAMPLING}

Water systems were tested once a month, with the number of people being served determining the number of samples collected. Samples were analyzed for the presence of coliform bacteria. Residual chlorine analyses are no longer required by the state.

No coliform bacteria were detected in any samples collected during the first quarter of 1996 .

\subsubsection{CHEMICAL ANALYSIS}

During the second quarter, all systems were sampled and analyzed for organics, including synthetic organics, nitrites, nitrates, and fluoride. Sample results were below the maximum concentration levels.

\subsection{SEWAGE LAGOONS}

During the second quarter of 1996, sampling was conducted for sewage lagoon systems at the NTS in accordance with state of Nevada General Permit, GNEV93001. Water parameters monitored included water depth in infiltration basins, monitoring of influent quality, and organic loading rates in sewage lagoons. The results for water depth measurements are shown in Table 11.0; influent quality data are shown in Table 12.0; and the results of organic loading rates are shown in Table 13.0. The results and data in these three tables are within permit limits.

The permit also requires sampling and analysis of infiltration basins which contain $30 \mathrm{~cm}$ or more of liquid in January and June of any year. The Area 6 Yucca Lake facility level exceeded the $30 \mathrm{~cm}$ limit during June 1996. The analytic results have not been received yet and will be reported next quarter.

Annual sampling of primary treatment lagoons at facilities which receive industrial wastewater for toxics listed in Appendix I of the permit was performed in April 1996. Analytical results were below compliance limits and are shown in Table 14.0.

\subsection{NON-HAZARDOUS SOLID WASTE DISPOSAL}

Monitoring of the three sanitary landfills was limited to recording daily refuse amounts by weight. Waste disposed of in the Area 23 landfill was weighed at the Gate 100 weighing station. Waste disposed of in the $10 \mathrm{c}$ crater landfill in Area 9 was weighted at the landfill site. Approximately 1500 tons of waste were disposed of in the Areas 6, 9, and 23 sanitary landfills during the second quarter of 1996, as shown in Table 15.0.

\subsection{NATIONAL ENVIRONMENTAL POLICY ACT}

The National Environmental Policy Act (NEPA) of 1969 requires all federal facilities, including the NTS, to account for environmental impacts, and potential alternatives, in conducting and 
planning their operations. In accordance with NEPA, the DOE Nevada (DOE/NV) activities are evaluated for their potential environmental impacts and to ensure that the proper level of NEPA documentation is initiated. During the second quarter of 1996, NTS-related NEPA activities included actions on 7 Environmental Impact Statements (EISs), 8 Environmental Assessments (EAs), and 16 Categorical Exclusions (CXs). Of these, $2 \mathrm{EAs}$ and $12 \mathrm{CXs}$ were initiated in the second quarter of 1996. These NEPA documents are listed in chronological order in Table 16.0 , with their assigned number and present status.

\subsection{ENVIRONMENTAL RESTORATION/REMEDIAL ACTIVITIES}

Work began in June 1996 on a process for removing plutonium contamination from the soil at the DOUBLE TRACKS site on the Nellis Range Complex. This activity was described in Environmental Assessment DOE/EA-1136 which had a Finding of No Significant Impact determination in March 1996. The design amount of surface soil was removed and stockpiled and the excavated area and stockpile were stabilized by June 29,1996 . The stockpile will be disposed of in the Area 3 LLW site.

\subsection{OTHER ACTIVITIES}

A series of experiments was conducted on the Navy Thermal Treatment Unit during February and March 1996 to assess its capabilities. Stack gas measurements during test burns of colored dyes will be used to determine whether or not the system reduces the level of hazardous combustion products to state and national standards.

The LGFSTF, renamed the HAZMAT Spill Center, has had onsite customers for about 20 weeks this year, with the remainder of the time devoted to facility maintenance. Experiments have been conducted by various entities, including: a collaborative effort by Los Alamos National Laboratory (LANL), Lawrence Livermore National Laboratory (LLNL), Brookhaven National Laboratory, and Sandia National Laboratories; the DuPont Corporation (mainly training of emergency operators); and a United Kingdom series consisting of Dual Source Releases.

\subsection{ECOLOGICAL ACTIVITIES}

\subsection{ENDANGERED SPECIES ACT COMPLIANCE}

\subsubsection{DESERT TORTOISE SURVEYS}

Field surveys for tortoises and onsite construction monitoring were conducted for road maintenance activities during the first quarter of 1996, and the tortoise-proof fences around sewage lagoons and the grenade range were inspected and needed fence repairs identified.

\subsubsection{PREACTIVITY SURVEYS}

Preactivity surveys are performed at selected sites to comply. with DOE Order 54XC.1B. A preactivity survey of 10 large areas of contaminated soil in Yucca Flat was conducted in the first quarter. A pair of burrowing owls (a former candidate species under the Endangered Species Act and a State-protected species) was found and their burrow flagged for avoidance. 
Two new candidate plant species for federal listing that may occur on the NTS were identified by the U.S. Fish and Wildlife Service (USFWS) in February. They include Clokey's egg-vetch (Astragalus oophorus var. clokeyanus) and the Blue Diamond cholla (Opuntia whipplei var. multigeniculata).

\subsection{ECOLOGICAL MONITORING}

Under the climate of changing NTS missions, a majority of the Basic Environmental Compliance and Monitoring Program tasks have been suspended. Efforts have thus focused on developing a new comprehensive and adaptive framework for ecological monitoring on the NTS. The result of this effort was a draft document produced in March 1996, Guiding Principles and

Prioritization Criteria for Ecological Monitoring at the Nevada Test Site. The following activities are planned:

- Unique Habitat and Sensitive Species Monitoring - In February 1996, the USFWS issued a revised list of species and candidates proposed for listing under the Endangered Species Act. The revised list from USFWS removed 11 of the 12 animals and all of the 12 plants on the NTS from candidate status. During this reporting period, study designs for field surveys for chuckwalla, burrowing owls, and five species of bats were prepared.

- Ecosystem Mapping and Description - Habitat mapping of the southern one-third of the NTS was initiated. Mapping will facilitate the preparation of EAs and the management of biological resources at the NTS. The study design for this effort was developed, and an inventory of existing aerial photographs was performed.

- Project Specific Monitoring - A biological monitoring plan for the HAZMAT Spill Center was developed in January 1996. Such monitoring is prescribed in the facility's programmatic EA for those chemicals for which there are uncertain modeling predictions of downwind air concentrations that have not been tested before, or that have not been tested in large quantities. The biological monitoring plan addresses the method for biota sampling to determine test impacts under these circumstances.

\subsection{LAND RECLAMATION}

Both the Comprehensive Environmental Response, Compensations, and Liability Act and the Superfund Amendments and Reauthorization Act require remediation of the safety shot sites on and around the NTS. In fiscal year 1996, DOUBLE TRACKS, near the Tonopah Test Range (TTR), was targeted for remediation, and assessments for the three CLEAN SLATE sites, located on the TTR, were also initiated. Remediation includes the excavation and removal of soil from the area surrounding the detonation site. Once the contaminated soils are removed, the site will be revegetated and released for unrestricted use.

\subsubsection{DOUBLE TRACKS SAFETY SHOT SITE}

Stabilization of areas disturbed by cleanup activities at the DOUBLE TRACKS safety shot site are planned for calendar year 1996. Stabilization is critical both for preventing resuspension of residual plutonium, thus reducing health hazards and for reestablishing wildlife habitat. It is done by application of a chemical soil stabilizer immediately after the disturbance and later, by reestablishing native plants to provide a habitat for local wildlife, thus complementing other actions being taken to release the site for future use. 
An irrigation study was initiated at field trial plots located adjacent to the DOUBLE TRACKS site to evaluate the effectiveness of different irrigation strategies in reestablishing native plants.

\subsection{OCCURRENCE REPORTING}

Occurrences are environmental, health, and/or safety-related events which are reported in several categories in accordance with the requirements of DOE Order 5000.3B. Two environmental occurrences were reported for NTS facilities during the second quarter of 1996. Details for these occurrences, including report numbers, description, and status, appear in Table 17.0. 
TABLES 
Table 1.0 Sample Collection and Analysis Schedule

\section{Frequency of Analyses}

\begin{tabular}{|c|c|c|c|c|c|c|}
\hline Network & Media & No. & Weekly & Monthly & Quarterly & Annually \\
\hline Air & $\begin{array}{l}\text { Particulate } \\
\text { RWMS } \\
\text { Tritium } \\
\text { Noble Gas }\end{array}$ & $\begin{array}{c}30 \\
15 \\
15 \\
3\end{array}$ & $\begin{array}{l}\beta, Y \\
\beta, Y \\
\\
{ }^{85} \mathrm{Kr}\end{array}$ & $\begin{array}{l}\text { Pu } \\
\text { Bi-weekly }\end{array}$ & $\mathrm{Pu}$ & \\
\hline Water & $\begin{array}{l}\text { Reservoir } \\
\text { Springs } \\
\text { Wells } \\
\text { Spigot } \\
\text { Sewage } \\
\text { Pond }\end{array}$ & $\begin{array}{c}15 \\
8 \\
12 \\
\\
7 \\
9 \\
2\end{array}$ & . & & $\begin{array}{c}\beta, Y, \alpha,{ }^{3} \mathrm{H}+, \mathrm{Sr} \\
\quad \mathrm{Pu},{ }^{226,228} \mathrm{Ra} \\
\beta, \gamma, \alpha,{ }^{3} \mathrm{H}, \mathrm{Pu} \\
\beta,{ }^{3} \mathrm{H}, \mathrm{Pu} \\
\beta, Y,{ }^{3} \mathrm{H}, \mathrm{Pu}\end{array}$ & $\begin{array}{l}\beta, y,{ }^{3} \mathrm{H}, \mathrm{Sr}, \mathrm{Pu} \\
\beta, y,{ }^{3} \mathrm{H}, \mathrm{Sr}, \mathrm{Pu}\end{array}$ \\
\hline TLD & Environ. & 168 & & & $Y$ & \\
\hline
\end{tabular}

Table 2.0 Derived Limits for Radionuclides in Air and Water (DOE Order 5400.5) $\mu \mathrm{Ci} / \mathrm{mL}$

Radionuclide

${ }^{3} \mathrm{H}$
${ }^{40} \mathrm{~K}$
${ }^{85} \mathrm{Kr}$
${ }^{90} \mathrm{Sr}$
${ }^{226,228} \mathrm{Ra}$
${ }^{238} \mathrm{Pu}$
${ }^{239+240} \mathrm{Pu}$

\section{$\underline{\mathrm{DCG}}$ (air) $^{(\mathrm{a})}$}

$1 \times 10^{-8}$

$9 \times 10^{-11}$

$3 \times 10^{-7}(\mathrm{c})$

$9 \times 10^{-13}$

$1 \times 10^{-13}$

$4 \times 10^{-15}$

$4 \times 10^{-15}$
DCG (water) ${ }^{(b)}$

$8 \times 10^{-5}$

$3 \times 10^{-7}$

$4 \times 10^{-8}$

$4 \times 10^{-9}$

$2 \times 10^{-9}$

$1 \times 10^{-9}$

(a) DCG - Derived Concentration Guides are reference values for conducting radiological protection programs at operational DOE facilities and sites. The DCG values for air are for an effective dose equivalent of $10 \mathrm{mrem}(0.1 \mathrm{mSv})$ (inhalation) for a year as required by 40 CFR 61.92 and DOE Order 5400.5 .

(b) The values listed for beta and photon emitters in the table are based on a 4 mrem committed effective dose equivalent for the radionuclide taken into the body by ingestion of water during one year $(730 \mathrm{~L})$. Gross beta levels less than or equal to 50 $\mathrm{pCi} / \mathrm{L}$ are in compliance with $40 \mathrm{CFR} 141$, SDWA.

(c) Nonstochastic value. 
Table 3.0 Summary Data for Gross $\alpha$, Gross $\beta$, and ${ }^{7} \mathrm{Be}$ in Air ( $\left.\mu \mathrm{Ci} / \mathrm{mL}\right)$, Second Quarter - 1996

Location (Area)

Area 1, BJY

Area 2,

Area 2, 2-1 Substation

Area 2, Mud Plant

Area 3, U-3ah/at South

Area 3, U-3ah/at East

Area 3, U-3ah/at North

Area 3, U-3ah/at West

Area 3, Well ER-3-1

Area 4, Bunker T-4

Area 5, RWMS No. 1

Area 5, RWMS No. 3

Area 5, RWMS No. 4

Area 5, RWMS No. 5

Area 5, RWMS No. 6

Area 5, RWMS No. 7

Area 5, RWMS No. 8

Area 5, RWMS No. 9

Area 5, RWMS PIT-5

Area 5, TRU Building North

Area 5, TRU Building South

Area 5, DOD

Area 5, Well 5B

Area 6, Yucca

$$
2.9 \times 10^{-13}
$$

Area $6, \mathrm{CP} 6$

Area 6, Well 3

Area 7, Ue7ns

Area 9, 9-300 Bunker

Area 10, Gate 700

Area 10, SEDAN Crater

Area 11, Gate 293

Area 12

Area 15, EPA Farm

Area 16, 3545 Substation

Area 18, Well UE-18t

Area 20, SCHOONER

Area 20

Area 23, Building 790 No. 2

Area 23, H\&S Building

Area 25, E-MAD North

Area 25, NRDS

Area 27

Network Averages
Gross $\alpha$

$2.2 \times 10^{-15}$

$1.4 \times 10^{-15}$

$4.0 \times 10^{-15}$

$4.0 \times 10^{-15}$

$3.3 \times 10^{-15}$

$4.0 \times 10^{-15}$

$3.0 \times 10^{-15}$

$2.4 \times 10^{-15}$

$1.4 \times 10^{-15}$

$4.1 \times 10^{-15}$

$1.8 \times 10^{-15}$

$2.4 \times 10^{-15}$

$2.7 \times 10^{-15}$

$1.8 \times 10^{-15}$

$1.6 \times 10^{-15}$

$1.9 \times 10^{-15}$

$3.0 \times 10^{-15}$

$2.4 \times 10^{-15}$

$2.7 \times 10^{-15}$

$2.5 \times 10^{-15}$

$2.6 \times 10^{-15}$
Gross $\beta$

$2.2 \times 10^{-14}$

$1.6 \times 10^{-14}$

$1.3 \times 10^{-14}$

$2.2 \times 10^{-14}$

$1.4 \times 10^{-14}$

$1.7 \times 10^{-14}$

$1.7 \times 10^{-14}$

$1.6 \times 10^{-14}$

$2.0 \times 10^{-14}$

$1.8 \times 10^{-14}$

$1.6 \times 10^{-14}$

$2.0 \times 10^{-14}$

$1.8 \times 10^{-14}$

$1.8 \times 10^{-14}$

$1.8 \times 10^{-14}$

$1.7 \times 10^{-14}$

$1.6 \times 10^{-14}$

$1.8 \times 10^{-14}$

$1.6 \times 10^{-14}$

$1.8 \times 10^{-14}$

$1.6 \times 10^{-14}$

$1.8 \times 10^{-14}$

$1.8 \times 10^{-14}$

$1.8 \times 10^{-15}$

$1.6 \times 10^{-14}$

$1.6 \times 10^{-14}$

$1.6 \times 10^{-14}$

$1.5 \times 10^{-14}$

$1.5 \times 10^{-14}$

$1.7 \times 10^{-14}$

$1.8 \times 10^{-14}$

$1.6 \times 10^{-14}$

$1.6 \times 10^{-14}$

$1.6 \times 10^{-14}$

$1.8 \times 10^{-14}$

$1.8 \times 10^{-14}$

$1.5 \times 10^{-14}$

$1.6 \times 10^{-14}$

$2.0 \times 10^{-14}$

$1.8 \times 10^{-14}$

$1.7 \times 10^{-14}$

$1.6 \times 10^{-14}$

$1.7 \times 10^{-14}$
Beryllium-7

$3.7 \times 10^{-13}$

$3.0 \times 10^{-13}$

$1.9 \times 10^{-13}$

$3.8 \times 10^{-13}$

$2.2 \times 10^{-13}$

$2.7 \times 10^{-13}$

$2.9 \times 10^{-13}$

$2.6 \times 10^{-13}$

$3.4 \times 10^{-13}$

$3.1 \times 10^{-13}$

$2.7 \times 10^{-13}$

$3.3 \times 10^{-13}$

$3.0 \times 10^{-13}$

$3.2 \times 10^{-13}$

$2.5 \times 10^{-13}$

$2.7 \times 10^{-13}$

$3.1 \times 10^{-13}$

$2.6 \times 10^{-13}$

$2.7 \times 10^{-13}$

$2.9 \times 10^{-13}$

$2.8 \times 10^{-13}$

$3.2 \times 10^{-13}$

$3.2 \times 10^{-13}$

$1.8 \times 10^{-14}$

$2.9 \times 10^{-13}$

$3.0 \times 10^{-13}$

$2.9 \times 10^{-13}$

$2.8 \times 10^{-13}$

$2.8 \times 10^{-13}$

$3.2 \times 10^{-13}$

$3.1 \times 10^{-13}$

$3.2 \times 10^{-13}$

$3.2 \times 10^{-13}$

$2.7 \times 10^{-13}$

$3.0 \times 10^{-13}$

$3.4 \times 10^{-13}$

$3.0 \times 10^{-13}$

$3.1 \times 10^{-13}$

$3.8 \times 10^{-13}$

$3.2 \times 10^{-13}$

$3.0 \times 10^{-13}$

$2.8 \times 10^{-13}$

$3.0 \times 10^{-13}$ 
Table 4.0 Offsite Particulate and Onsite ${ }^{85} \mathrm{Kr}$ in Air Summary Data, Second Quarter - 1996 Offsite Particulate Results $(\mu \mathrm{Ci} / \mathrm{mL})^{(\mathrm{a})}$

\begin{tabular}{lccccc} 
Location & Gross $\alpha$ & Gross $\beta$ & Bervllium-7 & $\underline{238} \mathrm{Pu}$ & \multicolumn{2}{c}{${ }^{239+240} \mathrm{Pu}$} \\
DOUBLE TRACKS & $2.96 \times 10^{-15}$ & $1.55 \times 10^{-14}$ & $3.11 \times 10^{-13}$ & $3.4 \times 10^{-19}$ & $3.1 \times 10^{-18}$ \\
CLEAN SLATE & $1.45 \times 10^{-14}$ & $1.50 \times 10^{-14}$ & $2.95 \times 10^{-13}$ & $-5.1 \times 10^{-20}$ & $1.2 \times 10^{-18}$ \\
Area 13 & $3.13 \times 10^{-15}$ & $1.60 \times 10^{-14}$ & $2.86 \times 10^{-13}$ & $4.9 \times 10^{-19}$ & $2.9 \times 10^{-17}$
\end{tabular}

(a) Particulate samples collected with solar-powered air sampler.

Onsite Krypton-85 Results $(\mu \mathrm{Ci} / \mathrm{mL})$

\begin{tabular}{llll} 
Location & Average & Maximum & Minimum \\
\cline { 2 - 4 } & $2.46 \times 10^{-11}$ & $3.29 \times 10^{-11}$ & $1.57 \times 10^{-11}$ \\
BJY & $4.67 \times 10^{-11}$ & $2.48 \times 10^{-10}$ & $1.47 \times 10^{-11}$ \\
Pahute Substation & $5.22 \times 10^{-11}$ & $1.15 \times 10^{-10}$ & $2.13 \times 10^{-11}$ \\
Area 20 & & & \\
\hline
\end{tabular}

Table 5.0 Summary Data for Plutonium in Air Samples, First Quarter - 1996 ${ }^{(a)}$

Location (Area)

Area 1 BJY

Area 2

Area 2 2-1 Substation

Area 2 Mud Plant

Area 3 U-3ah/at South

Area 3 U-3ah/at East

Area 3 U-3ah/at North

Area 3 U-3ah/at West

Area 3 Well ER-3-1

Area 4 Bunker T-4

Area 5 RWMS No. 1

Area 5 RWMS No. 3

Area 5 RWMS No. 4

Area 5 RWMS No. 5

Area 5 RWMS No. 6

Area 5 RWMS No. 7

Area 5 RWMS No. 8

Area 5 RWMS No. 9

Area 5 RWMS Pit-5

Area 5 RWMS TP Building North

Area 5 RWMS TP Building South
$\stackrel{238}{\mathrm{Pu}}$

${ }^{239+240} \mathrm{Pu}$

$-1.4 \times 10^{-19}$

$-1.2 \times 10^{-19}$

$1.1 \times 10^{-18}$

$1.3 \times 10^{-18}$

$1.8 \times 10^{-18}$

$1.0 \times 10^{-18}$

$-1.4 \times 10^{-19}$

$-2.1 \times 10^{-19}$

$2.5 \times 10^{-18}$

$5.5 \times 10^{-19}$

$4.5 \times 10^{-19}$

$1.2 \times 10^{-18}$

$1.0 \times 10^{-18}$

$-2.7 \times 10^{-19}$

$-2.3 \times 10^{-19}$

$-5.0 \times 10^{-19}$

$1.4 \times 10^{-18}$

$2.2 \times 10^{-19}$
$2.3 \times 10^{-18}$

$1.3 \times 10^{-18}$

$4.5 \times 10^{-17}$

$5.1 \times 10^{-17}$

$1.4 \times 10^{-16}$

$1.1 \times 10^{-16}$

$3.5 \times 10^{-18}$

$4.0 \times 10^{-18}$

$1.7 \times 10^{-18}$

$6.3 \times 10^{-19}$

$4.1 \times 10^{-18}$

$4.6 \times 10^{-18}$

$2.6 \times 10^{-17}$

$5.0 \times 10^{-18}$

$2.2 \times 10^{-18}$

$4.9 \times 10^{-18}$

$3.5 \times 10^{-18}$

$4.0 \times 10^{-19}$

(a) Data not available for the first quarter report. 
Table 5.0 (Summary Data for Plutonium in Air Samples, First Quarter - 1996 ${ }^{\text {(a) }}$, cont.)

Location (Area)

Area 5 DOD

Area 5 Well 5B

Area 6 Yucca

Area 6 CP 6

Area 6 Well 3

Area 7 Ue7ns

Area 9 9-300

Area 10 Gate 700

Area 10 SEDAN Crater

Area 11 Gate 293

Area 12

Area 15 EPA Farm

Area 163545 Substation

Area 18 Well UE-18t

Area 20 SCHOONER

Area 20

Area 23 Building 790 No. 2

Area $23 \mathrm{H} \& S$ Building

Area 25 E-MAD North

Area 25 NRDS

Area 27
$\stackrel{238}{\mathrm{Pu}}$

$\underline{239+240 \mathrm{Pu}}$

$-1.3 \times 10^{-19}$
$-1.4 \times 10^{-19}$
$5.5 \times 10^{-19}$
$2.4 \times 10^{-19}$
$3.0 \times 10^{-18}$
$2.6 \times 10^{-19}$
$3.3 \times 10^{-18}$
$-1.8 \times 10^{-19}$
$1.0 \times 10^{-18}$
$-1.9 \times 10^{-19}$

$-1.8 \times 10^{-19}$

$1.4 \times 10^{-18}$
$1.2 \times 10^{-17}$

$5.6 \times 10^{-18}$

$1.6 \times 10^{-17}$

$6.5 \times 10^{-18}$

$2.1 \times 10^{-16}$

$4.0 \times 10^{-18}$

$2.8 \times 10^{-17}$

$5.0 \times 10^{-18}$

$-6.7 \times 10^{-20}$

$2.4 \times 10^{-17}$

Average

$6.7 \times 10^{-19}$

$2.5 \times 10^{-17}$

(a) Data not available for first quarter report.

Table 6.0 Tritium in Atmospheric Moisture Summary Data, Second Quarter - 1996

Location (Area)

Area 1 BJY

Area 3 Mud Plant

Area 5 RWMS No. 1

Area 5 RWMS No. 3

Area 5 RWMS No. 4

Area 5 RWMS No. 5

Area 5 RWMS No. 6

Area 5 RWMS No. 7

Area 5 RWMS No. 8

Area 5 RWMS No. 9

Area 10 SEDAN Crater

Area 12

Area 12 E Tunnel Pond

Area 15 EPA Farm

Area $23 \mathrm{H} \& \mathrm{~S}$ Building

Average
Average

$4.2 \times 10^{-13}$

$4.3 \times 10^{-13}$

$1.7 \times 10^{-12}$

$1.0 \times 10^{-12}$

$5.8 \times 10^{-12}$

$2.0 \times 10^{-12}$

$2.2 \times 10^{-12}$

$2.0 \times 10^{-12}$

$2.8 \times 10^{-12}$

$2.3 \times 10^{-12}$

$9.3 \times 10^{-12}$

$1.2 \times 10^{-12}$

$1.0 \times 10^{-11}$

$2.7 \times 10^{-12}$

$4.8 \times 10^{-13}$

$3.0 \times 10^{-12}$
Maximum

Minimum

$7.4 \times 10^{-13}$

$1.5 \times 10^{-12}$

$3.1 \times 10^{-12}$

$2.1 \times 10^{-12}$

$1.2 \times 10^{-11}$

$4.1 \times 10^{-12}$

$5.2 \times 10^{-12}$

$3.8 \times 10^{-12}$

$7.4 \times 10^{-12}$

$3.7 \times 10^{-12}$

$1.9 \times 10^{-11}$

$5.5 \times 10^{-12}$

$1.6 \times 10^{-11}$

$3.4 \times 10^{-12}$

$1.1 \times 10^{-12}$
$1.0 \times 10^{-13}$

$-8.1 \times 10^{-13}$

$-4.0 \times 10^{-13}$

$-5.4 \times 10^{-14}$

$1.5 \times 10^{-12}$

$5.9 \times 10^{-13}$

$-3.0 \times 10^{-13}$

$4.3 \times 10^{-13}$

$-8.2 \times 10^{-14}$

$1.0 \times 10^{-12}$

$1.5 \times 10^{-12}$

$-1.2 \times 10^{-12}$

$-4.8 \times 10^{-13}$

$1.7 \times 10^{-12}$

$-3.2 \times 10^{-13}$ 
Table 7.0 Summary Data for Well and Surface Water Samples, Second Quarter - 1996

\section{Ground Water $(\mu \mathrm{Ci} / \mathrm{mL})$}

\begin{tabular}{|c|c|c|c|c|c|c|c|}
\hline Well Name & $\begin{array}{l}\text { Gross } \\
\text { Alpha }\end{array}$ & $\begin{array}{l}\text { Gross } \\
\text { Beta }\end{array}$ & $\begin{array}{l}\text { Enrich. } \\
\text { Tritium }^{(a)} \\
\end{array}$ & ${ }^{226} \mathrm{Ra}^{(\mathrm{a})}$ & ${ }^{238} \mathrm{Pu}$ & ${ }^{239+240} \mathrm{Pu}$ & ${ }^{90} \mathrm{Sr}$ \\
\hline \multicolumn{8}{|c|}{ Potable Wells } \\
\hline Vell $5 B$ & $6.3 \times 10^{-9}$ & $1.2 \times 10^{-9}$ & $4.1 \times 10^{-9}$ & $1.3 \times 10^{-9}$ & $9.3 \times 10^{-14}$ & $2.2 \times 10^{-12}$ & $2.5 \times 10^{-11}$ \\
\hline lell $5 C$ & $1.5 \times 10^{-9}$ & $9.2 \times 10^{-9}$ & $2.5 \times 10^{-9}$ & $-1.2 \times 10^{-9}$ & $7.0 \times 10^{-12}$ & $6.7 \times 10^{-12}$ & $8.3 \times 10^{-11}$ \\
\hline Well 4A & $9.6 \times 10^{-9}$ & $6.1 \times 10^{-9}$ & & & $-2.2 \times 10^{-12}$ & $7.3 \times 10^{-12}$ & \\
\hline Well 4 & $1.1 \times 10^{-9}$ & $6.9 \times 10^{-9}$ & $-7.7 \times 10^{-10}$ & $2.3 \times 10^{-9}$ & $9.0 \times 10^{-12}$ & $5.5 \times 10^{-12}$ & $9.9 \times 10^{-11}$ \\
\hline Well C-1 & $1.5 \times 10^{-9}$ & $1.6 \times 10^{-9}$ & $-2.0 \times 10^{-9}$ & $2.9 \times 10^{-9}$ & $6.4 \times 10^{-12}$ & $3.9 \times 10^{-12}$ & $6.9 \times 10^{-11}$ \\
\hline Well UE-16d & $7.5 \times 10^{-9}$ & $7.3 \times 10^{-9}$ & $3.9 \times 10^{-9}$ & $2.4 \times 10^{-9}$ & $6.7 \times 10^{-12}$ & $6.4 \times 10^{-12}$ & $2.4 \times 10^{-11}$ \\
\hline Well HTH 8 & $9.2 \times 10^{-10}$ & $3.8 \times 10^{-9}$ & $4.8 \times 10^{-9}$ & $1.8 \times 10^{-9}$ & $5.5 \times 10^{-12}$ & $8.0 \times 10^{-12}$ & $1.8 \times 10^{-11}$ \\
\hline Well Army \#1 & $2.9 \times 10^{-9}$ & $3.1 \times 10^{-9}$ & $2.4 \times 10^{-9}$ & $5.8 \times 10^{-10}$ & $4.5 \times 10^{-12}$ & $6.7 \times 10^{-12}$ & $1.6 \times 10^{-10}$ \\
\hline Well $\mathrm{J}-12$ & $1.8 \times 10^{-9}$ & $4.3 \times 10^{-9}$ & $1.1 \times 10^{-9}$ & $1.2 \times 10^{-10}$ & $7.8 \times 10^{-12}$ & $7.5 \times 10^{-12}$ & $2.4 \times 10^{-11}$ \\
\hline Well J-13 & $1.2 \times 10^{-9}$ & $4.5 \times 10^{-9}$ & $-2.0 \times 10^{-10}$ & $1.7 \times 10^{-9}$ & $7.0 \times 10^{-12}$ & $6.7 \times 10^{-12}$ & $3.9 \times 10^{-11}$ \\
\hline
\end{tabular}

(a) All ${ }^{228} \mathrm{Ra}$ and tritium values are near or below the MDC.

Industrial Wells

$\begin{array}{llllllll}\text { Well UE-5c } & 9.2 \times 10^{-9} & 6.3 \times 10^{-9} & 4.0 \times 10^{-10} & 4.6 \times 10^{-10} & 8.5 \times 10^{-12} & 8.2 \times 10^{-12} & 5.9 \times 10^{-11} \\ \text { Network Avg. } 7.3 \times 10^{-9} & 7.2 \times 10^{-9} & 1.7 \times 10^{-9} & 1.1 \times 10^{-9} & 5.5 \times 10^{-12} & 6.3 \times 10^{-12} & 6.0 \times 10^{-11}\end{array}$

\section{Sewage Lagoons $(\mu \mathrm{Ci} / \mathrm{mL})$}

\begin{tabular}{|c|c|c|c|c|c|}
\hline Name & Gross Beta & Tritium & ${ }^{137} \mathrm{Cs}$ & ${ }^{238} \mathrm{Pu}$ & ${ }^{239} \mathrm{Pu}$ \\
\hline RWMS Pond & $3.4 \times 10^{-8}$ & $2.4 \times 10^{-7}$ & NA & $-1.1 \times 10^{-11}$ & $-2.8 \times 10^{-12}$ \\
\hline Yucca Pond & $2.4 \times 10^{-8}$ & $2.4 \times 10^{-7}$ & NA & $1.5 \times 10^{-13}$ & $-3.1 \times 10^{-12}$ \\
\hline DAF Pond & $3.0 \times 10^{-8}$ & $3.4 \times 10^{-7}$ & NA & $-7.5 \times 10^{-12}$ & $-3.5 \times 10^{-12}$ \\
\hline LANL Pond & $2.3 \times 10^{-8}$ & $2.3 \times 10^{-7}$ & NA & $1.3 \times 10^{-13}$ & $-7.2 \times 10^{-12}$ \\
\hline A-12 Pond & $1.2 \times 10^{-8}$ & $8.2 \times 10^{-8}$ & NA & $-5.1 \times 10^{-12}$ & $-7.5 \times 10^{-12}$ \\
\hline A-22 Pond & $4.5 \times 10^{-8}$ & $2.2 \times 10^{-8}$ & NA & $-8.4 \times 10^{-12}$ & $-8.1 \times 10^{-12}$ \\
\hline A-23 Pond & $4.5 \times 10^{-8}$ & $3.4 \times 10^{-7}$ & NA & $-3.0 \times 10^{-12}$ & $2.4 \times 10^{-13}$ \\
\hline Central Support & $2.6 \times 10^{-8}$ & $2.8 \times 10^{-7}$ & NA & $-6.1 \times 10^{-12}$ & $-5.7 \times 10^{-12}$ \\
\hline
\end{tabular}

(NA) Not Analyzed

Containment Ponds ( $\mu \mathrm{Ci} / \mathrm{mL})$

Name

Gross Beta

${ }^{137} \mathrm{Cs}$

$\stackrel{{ }^{238} \mathrm{Pu}}{ }$

${ }^{239} \mathrm{Pu}$

E Tunnel \#1

$1.0 \times 10^{-3}$

ETunnel Ef

$6.1 \times 10^{-8}$

$7.8 \times 10^{-4}$

$1.8 \times 10^{-7}$

$2.3 \times 10^{-10}$

$2.1 \times 10^{-9}$ 
Table 8.0 Faucet Water Sample Summary Results $(\mu \mathrm{Ci} / \mathrm{mL})$, Second Quarter - 1996

\begin{tabular}{|c|c|c|c|c|c|}
\hline Location (Area) & Gross $\alpha$ & Gross $\beta$ & ${ }^{238} \mathrm{Pu}$ & ${ }^{239+240} \mathrm{Pu}$ & Tritium \\
\hline Area 1, Building 101 & $7.5 \times 10^{-9}$ & $6.5 \times 10^{-9}$ & $-9.6 \times 10^{-12}$ & $-9.1 \times 10^{-12}$ & $6.0 \times 10^{-5}$ \\
\hline Area 2, Restroom & $8.9 \times 10^{-10}$ & $3.9 \times 10^{-9}$ & $-4.3 \times 10^{-12}$ & $-6.2 \times 10^{-12}$ & $1.2 \times 10^{-}$ \\
\hline Area 6, Cafeteria & $5.7 \times 10^{-9}$ & $8.0 \times 10^{-9}$ & $-4.3 \times 10^{-12}$ & $-4.0 \times 10^{-12}$ & $-1.4 \times 10^{-}$ \\
\hline Area 6, Building 6-900 & $9.8 \times 10^{-9}$ & $7.0 \times 10^{-9}$ & $-4.4 \times 10^{-12}$ & $-4.0 \times 10^{-12}$ & $1.0 \times 10^{-}$ \\
\hline Area 12, Building 12-23 & $1.0 \times 10^{-9}$ & $4.5 \times 10^{-9}$ & $-6.8 \times 10^{-12}$ & $-6.5 \times 10^{-12}$ & $1.3 \times 10^{-}$ \\
\hline Mercury, Cafeteria & $5.8 \times 10^{-9}$ & $1.0 \times 10^{-8}$ & $-1.2 \times 10^{-11}$ & $-1.2 \times 10^{-11}$ & $3.4 \times 10^{-}$ \\
\hline Area 25, Building 4221 & $1.6 \times 10^{-9}$ & $5.2 \times 10^{-9}$ & $-1.9 \times 10^{-12}$ & $-2.2 \times 10^{-12}$ & $-2.2 \times 10^{-}$ \\
\hline Network Average & $4.6 \times 10^{-9}$ & $6.5 \times 10^{-9}$ & $-6.2 \times 10^{-12}$ & $-6.2 \times 10^{-12}$ & $7.7 \times 10^{-8}$ \\
\hline
\end{tabular}

Table 9.0 Background Radiation Measurements with TLDs, First Quarter - $1996^{(a)}$

\begin{tabular}{lllr} 
Location (Area) & mR/yr & Location & $\underline{\mathrm{mR} / \mathrm{yr}}$ \\
\cline { 2 - 4 } Area 3, Hill Top & 135 & Area 20, Stake LC-4 & 172 \\
Area 5, Well 5B & 110 & Area 20, Stake A-118 & 135 \\
Area 5, 3.3 mi SE Agg pit & 62 & Area 22, Army Well \#1 & Lost \\
Area 6, CP-6 & 84 & Area 23, Bldg 650 Dos. & 44 \\
Area 6, Yucca Oil Storage & 95 & Area 23, Bldg 650 Roof & 44 \\
Area 9, Papoose Lk Rd & 80 & Area 23, Post Office & 62 \\
Area 11, E of U-11b & 124 & Area 25, NRDS Warehse & 117 \\
Area 12, Gold Meadows & 106 & Area 25, HENRY Site & 120 \\
Area 15, U-15e Substatn & 95 & Area 25, Jackass \& A27 Rds & 77 \\
Area 19, Stake C-16 & 150 & Area 25, Guard Sta 510 & 113 \\
Area 19, Stake R-29 & 142 & Area 25, Yucca Mtn & 128 \\
Area 19, Gate 19-3P & 146 & Area 27, Area 27 Cafe & 124 \\
Area 20, Stake J-41 & 120 & Area 30, Gate 30-3P & Not Coll.
\end{tabular}

(a) Data not available for the first quarter report.

Table 10.0 Tritium in Soil Moisture, RWMS-5 $-\mathrm{nCi} / \mathrm{m}^{3}$

\section{Months From First Sampling}

$\begin{array}{llllllll}\text { Depth } & \text { Start } & \underline{8} & \underline{13} & \underline{17} & \underline{21} & \underline{25} & \underline{30} \\ 10 & 2 & 1 & 4 & 2 & 3 & 5.5 & 4 \\ 20 & 19 & 20 & 19 & 13 & 14 & 18 & 14 \\ 30 & 11 & 10 & 10 & 7.5 & 8 & 10 & 10 \\ 40 & 11 & 10 & 11 & 8 & 8.5 & 12 & 12\end{array}$


Table 10.0 (Tritium in Soil Moisture, RWMS-5 $-\mathrm{nCi} / \mathrm{m}^{3}$, cont.)

Months From First Sampling, Cont.

\begin{tabular}{llllllll} 
Depth & Start & $\underline{8}$ & $\underline{13}$ & $\underline{17}$ & $\underline{21}$ & $\underline{25}$ & $\underline{30}$ \\
50 & 6.5 & 6 & 7 & 6 & 7 & 29 & 36 \\
65 & 6.2 & 62 & 82 & 65 & 81 & 4760 & 3040 \\
85 & 1120 & 1450 & 10000 & 12000 & 13700 & 24400 & 29400 \\
110 & 0 & 0 & 1540 & 1090 & 1120 & 1470 & 1380 \\
119 & 342 & 268 & 399 & 313 & 376 & 469 & 426 \\
Depth & & $\underline{32}$ & $\underline{38}$ & $\underline{42}$ & $\underline{45}$ & $\underline{50}$ & $\underline{57}$ \\
10 & & 4 & 12 & 7 & 5 & 10 & 8 \\
20 & & 14 & 24 & 15 & 14 & 19 & 14 \\
30 & & 8 & 13 & 10 & 9 & 11 & 10 \\
40 & & 12 & 16 & 15 & 13 & 15 & 1450 \\
65 & & 35 & 57 & 58 & 53 & 68 & 77 \\
85 & & 2490 & 3580 & 2970 & 1480 & 3390 & 3050 \\
110 & & 28600 & 58600 & 55900 & 72300 & 62000 & 99000 \\
119 & & 1420 & 2240 & 1920 & 1830 & 2530 & 2350 \\
& & 0 & 812 & 541 & 686 & 853 & 803 \\
\hline
\end{tabular}

Table 11.0 Pond Water Depths in Infiltration Basins, Second Quarter - 1996

Impound

Gate 100, Basin

Mercury, Basin

Yucca Lake

North Basin

South Basin

Tweezer

East Basin

West Basin

CP-6

East Basin

West Basin

CP-72

DAF

Basin 1

Basin 2

Reactor Control, Basin

Test Stand 1, Basin

Test Cell C, Basin

Base Camp 25, Basin

Base Camp 12, Basin 1

Basin 2

Basin 3

Basin 4

Basin 5

RWMS-5, Basin 1

Basin 2
Maximum Operating

Depth. cm

90

180

140

140

244

244

90

90

90

150

150

130

90

90

100

120

120

120

120

120

150

150
Average Depth, $\mathrm{cm}$ (the first Quarter)

0

0

75

16

0

0

0

0

0

0

0

0

0

0

0

0

0

0

0

0

0 
Table 12.0 Influent Quality, Second Quarter - 1996

$\begin{array}{lrl}\text { Facility } & \begin{array}{c}\text { BOD5 (a) } \\ (\mathrm{mg} / \mathrm{L})\end{array} & \begin{array}{c}\text { S.C.(b) } \\ (\mu \mathrm{mhos} / \mathrm{cm})\end{array} \\ \text { Gate 100 } & 476 & 1.40 \\ \text { Mercury } & 98 & 0.80 \\ \text { Yucca Lake } & 98 & 0.86 \\ \text { Tweezer } & 81 & 0.76 \\ \text { CP-6 } & 0 & 0 \\ \text { CP-72 } & 0 & 0 \\ \text { DAF } & 20 & 1.22 \\ \text { Reactor Control } & 0 & 0 \\ \text { Test Stand 1 } & 0 & 0 \\ \text { Base Camp 25 } & 164 & 0.91 \\ \text { Base Camp 12 } & 13 & 0.48 \\ \text { Test Cell C } & 0 & 0 \\ \text { RWMS-5 } & 391 & 1.30\end{array}$

(a) Biochemical oxygen demand.

(b) Specific conductivity.

Table 13.0 Organic Loading Rates, Second Quarter - 1996

Facility

Mercury

Yucca Lake

Base Camp 12

LANL on Tweezer

RWMS-5

CP-6

CP-72

DAF

Reactor Control

Eng Test Stand

Test Cell C

Base Camp 25

Gate 100

\section{Limit (Kg/day)}

172

8.6

54

5.0

0.955

8.7

1.1

7.6

4.2

2.3

1.3

7.4

2.4
Mean Daily Load

Metered Rates

38.14

4.48

0.04

0.92

.56

Calculated Rates

$0^{\text {(a }}$

$0^{(a)}$

0.25

0

$0^{(a)}$

$0^{(a)}$

1.19

1.77

(a) Samples not taken due to inadequate or nonexistent flow. 
Table 14.0 Influent Toxics for Facilities that Receive Industrial Wastewater, Second Quarter 1996

Parameter

Action Level (mg/L)

Measurement (mg/L)

\section{Area 6 Yucca Lake}

Lead

Cresol, total

5.0

0.0143

200

0.013

\section{Area 23 Mercury}

Arsenic

Lead

Cresol, total
5.0
0.0205
5.0
0.0051
200
0.012

Area 25 Base Camp

Arsenic

5.0

0.0183

Area 6 Tweezer

Cresol, total

200

0.061

Area 6 DAF

Arsenic

5.0

0.0139

Area 5 RWMS

Arsenic

5.0

0.0104

Table 15.0 Quantity of Waste Disposed of in Landfills, Second Quarter - 1996

Quantity.(in pounds)

$\begin{array}{lrrr}\text { Month } & \text { Area 9 } & \text { Area 23 } & \text { Area 6 } \\ \text { January } & 864,742 & 236,530 & 129,430 \\ \text { February } & 783,690 & 323,100 & 6,200 \\ \text { March } & 412,290 & 257,020 & 47,852 \\ \text { Total } & 2,060,722 & 816,650 & 183,482\end{array}$


Table 16.0 NEPA Documentation Open, Second Quarter - 1996

File

Number

Description

Category Status $^{(a)}$

NV-93-025 Fire Training Facility, Area 23

EA Pending

NV-94-020 Pantex Sitewide EIS

NV-94-023 Transportation of BOMARC Missle Site

Contaminated Material Area 5

NV-94-026

Liquid Waste Treatment Facility, Area 6

NV-94-033 Storage and Disposition of Fissile Nuclear Materials, DOE

NV-94-050

Foreign Research Reactor Spent Nuclear Fuel

NV-94-056

National Ignition Facility

NV-95-011

Stockpile Stewardship and Management

NV-95-032

Sitewide EIS for LANL, NTS/LANL

NV-95-046

SNL Offsite Transportation of LLW, Areas 3 \& 5

NV-95-047

Yucca Mountain EIS, Area 25

NV-95-062

RF Characterization Capability, Tweezer Facility, Area 11

NV-95-066

Area 5 LLW Management Site Improvement Project

NV-96-002

Cotter Concentrate Treatment Facility, Area 5

NV-96-006

High Explosives Research and Development

(Weapons Effects Testing), Area 12

NV-96-007

Develop, and Test Pulsed Neutron Generator Concepts, NLV

EIS

Pending

NV-96-008

SNT-96-001 Radio Frequency Electromagnetic Testing, TTR

EA

EA

EIS

EIS

EIS

PEIS

EIS

EA

EIS

CX

EA

EA

Pending

NV-96-009

Borehole Drilling \& Characterization at Area 3, U3ah/at

NV-96-010

Site-wide Lead Cleanup Program

NV-96-011

Corrective Action Investigation of CLEAN SLATE Sites, TTR

NV-96-012

Waste Examination Facility, Area 5

NV-96-013 Mixed Waste Disposal Units, Area 5

NV-96-014 Transportation of Mixed Waste Offsite, Area 5

NV-96-015 Lead Contaminated Soil, Area 6

NV-96-016 Area 3 Soil Trench Excavation \#1

NV-96-017 Free Air CO ${ }_{2}$ Enrichment Facility, Area 5

NV-96-018 Reconstruction of 100-yr Storm Protection Channel, Area 5

NV-96-019 Area 25 Captive Flight Testing

NV-96-020 Corrective Action Investigation of Project Shoal Area

NV-96-021 EMF Installation for DAF Lightning Detection, Areas 5 \& 6

NV-96-022 Remediation of Area 2 Bitcutter Shop \& LLNL Postshot Injection Wells

$\mathrm{CX}$

$\mathrm{CX}$

$\mathrm{CX}$

Pending

Pending

05/17/96

Pending

Pending

Pending

Pending

Pending

Pending

- Pending

Pending

$\mathrm{CX}$

$\mathrm{CX}$

CX

Pending

Pending

05/06/96

$04 / 26 / 96$

$04 / 26 / 96$

EA

04/26/96

EA

04/26/96

EA

Pending

CX

05-24-96

cX

06-07-96

CX

$06 / 11 / 96$

CX

06/13/96

cX

06/13/96

cX

06/13/96

cX

06/13/96

CX

$06 / 28 / 96$

CX

06/28/96

(a) Date entry is date approved. 
Table 17.0 Environmental Occurrences at NTS Facilities, Second Quarter - 1996

Date $\quad \underline{\text { Report Number }} \quad \underline{\text { Description }}$ Status

06/04/96 NVOO-BNOO-NTS Historic fuel leak discovered when Pending

1996-0007 underground storage tank removed

06/12/96 NVOO-BNOO-NTS Historic fuel leak discovered when

underground storage tank removed

Pending 


\section{DISTRIBUTION LIST}

EPA

Director, Radiation Sciences Laboratory, U.S. Environmental Protection Agency, Post Office Box 93478, Las Vegas, NV 89193-3478, M/S 513

A. A. Mullen, Radiation Sciences Laboratory, U.S. Environmental Protection Agency, Post Office Box 93478, Las Vegas, NV 89193-3478, M/S 513

LANL

C.F. Eberhart, M/S F670, Los Alamos National Laboratory, Post Office Box 1663, Los Alamos, NM 87545 (2)

E. H. Essington, M/S J495, Los Alamos National Laboratory, Post Office Box 1663, Los Alamos, NM 87545

\section{LLNL}

Resident Manager, Lawrence Livermore National Laboratory, Post Office Box 45, Mercury, NV 89023, M/S 777

L. Anspaugh, Risk Sciences Center, L-453, Lawrence Livermore National Laboratory, Post Office Box 808, Livermore, CA 94551

$\underline{\text { SNL }}$

Resident Manager, Sandia National Laboratories, Post Office Box 38, Mercury, NV 89023

DSWA

D. A. Bedsun, Defense Special Weapons Agency, Post Office Box 98539, Las Vegas, NV 89193, M/S 573

BN

Manager, Bechtel Nevada, Post Office Box 98521, Las Vegas, NV 89193-8521, M/S NLV001

Manager, Environmental Management Division, Bechtel Nevada, Post Office Box 98521 , Las Vegas, NV 89193-8521, M/S NLV022

R. Brooksbank, Analytical Services Project, Bechtel Nevada, Post Office Box 98521 , Las Vegas, NV 89193-8521, M/S NTS279 (2)

Manager, Waste Management Department, Bechtel Nevada, Post Office Box 98521, Las Vegas, NV 89193-8521, M/S NLV080

O. L. Haworth, Environmental Management Division, Bechtel Nevada, Post Office Box 98521 , Las Vegas, NV 89193-8521, M/S NTS110 


\section{Distribution List, cont.}

R. R. Kinnison, Analytical Services Project, Bechtel Nevada, Post Office Box 98521, Las Vegas, NV 89193-8521, M/S NLV082

Manager, Environment, Safety, Health \& Quality Division, Bechtel Nevada, Post Office Box 98521, Las Vegas, NV 89193-8521, M/S NTS265

\section{DOE/NV}

Director, Environmental Protection Division, Nevada Operations Office, U.S. Department of Energy, Post Office Box 98518, Las Vegas, NV 89193-8518, M/S 505

N. G. McNeil, Environmental Protection Division, Nevada Operations Office, U.S.

Department of Energy, Post Office Box 98518, Las Vegas, NV 89193-8518, M/S 505

Technical Information Resource Center, Nevada Operations Office, U.S. Department of Energy, Post Office Box 98518, Las Vegas, NV 89193-8518, M/S 505

\section{Miscellaneous}

Office of Scientific and Technical Information, Technical Center, U.S. Department of Energy, Post Office Box 62, Oak Ridge, TN 37831 (2) 